\title{
Accounting Conservatism and Intellectual Capital: Evidence From Turkey With Comparison Models and Sectors
}

\author{
Uğur BELLiKLi ${ }^{1} \odot$, Abdulkerim DAȘTAN²®
}

\begin{abstract}
The aim of this study is to investigate the relevance between accounting conservatism and intellectual capital in the context of the contribution of accounting conservatism to intellectual capital. Four different measurement methods [the asymmetric timeliness of the earnings, market-to-book ratio, asymmetry of the accruals and cash flows and negative accruals] were employed in the study to measure both accounting conservatism and intellectual capital. In this study, research data based on listed companies in manufacturing industry and financial institutions of Borsa Istanbul (BIST) 100 Index in Turkey. The method of the study was the panel data analysis in which the effect of accounting conservatism on intellectual capital was examined based on the data of the predetermined this companies for 2006-2017 period. As a result of the findings, it was determined that the companies care about intellectual capital, and although there is a difference according to the measurement methods, accounting conservatism has an effect on intellectual capital, which is observed both positively that more prominent in financial institutions and negatively, and companies that have conservative accounting policies.
\end{abstract}

Keywords: Accounting conservatism; beneficial financial information; intellectual capital; Companies in listed BIST 100 Index.

\section{INTRODUCTION}

Consider an example of an enterprise that has a strong intellectual capital structure at the level we can measure and assume that the measured level of the conservative accounting of this enterprise is high. Right at this point, would it be possible to find an answer to the following question? "Does the high conservatism level of a company cause that it has a strong intellectual capital structure, or does the strong intellectual capital structure bring with it the conservative attitude of the company?"This study seeks the answer to this question and evaluates the issue in the light of the findings of analyzes in terms of the effect or contribution of conservative accounting policies on the intellectual capital structure.

The fact that there are limited number of studies that directly deal with the relationship between accounting conservatism and intellectual capital in the literature and that only a limited number of studies deal with the subject in general was the starting point of the present study.

In these limited number of studies, it is stated that they argued that conservative accounting practices suppressed intellectual capital, and emphasized the negative aspects of the relevance between accounting conservatism and intellectual capital (Amir and Lev, 1996; Brennan, 2001; Lev, 2001; Holland, 2003; Sofian et al., 2011). However, the fact that the subjects with which accounting conservatism was investigated (corporate social responsibility, auditing and auditor quality, management of earnings, etc.) have common aspects with intellectual capital, accounting conservatism aims to protect the interests of the parties of the enterprise. Besides, intellectual capital is also a part of this aim for taking the business further may provide a more positive approach to the relationship between accounting conservatism and intellectual capital. In addition, it is possible to argue that every enterprise

'Dr. Öğr. Üyesi, Giresun Üniversitesi, Alucra Turan Bulutcu Meslek Yükseokulu, Yönetim ve Organizasyon Bölümü, ugur.bellikli@giresun.edu.tr

${ }^{2}$ Prof. Dr., Karadeniz Teknik Üniversitesi, İktisadi ve İdari Bilimler Fakültesi, İşletme Bölümü,akdastan@ktu.edu.tr 
that sustains its existence in a proper way contributes to the accumulation of the intellectual capital. In brief, it is possible to bring alternative and more positive perspectives to the opinion claiming that conservative reporting prevents intellectual capital from becoming prominent in the literature (Bellikli, 2019).

It is possible to name the structure and understanding of the management, relations with customers, the level of knowledge and quality of employees, technological opportunities, and the ability to use them as "the factors that may affect the intellectual capital structure at the enterprise level" (Martensson 2000:210). In addition to these factors, to what extent can the conservative accounting policies that are applied in enterprises have an impact on the intellectual capital? In one sense, the purpose of this study, which aimed to question this effect, was to investigate the relationship between accounting conservatism and intellectual capital in terms of the contribution of accounting conservatism to intellectual capital based on the data of manufacturing industry and financial institutions of Borsa Istanbul (BIST) 100 Index in Turkey. The method of the study was the panel data analysis in which the effect of accounting conservatism on intellectual capital was examined based on the data of the predetermined this companies for 2006-2017 period. In addition to directly dealing with the effect of accounting conservatism on intellectual capital, the use of four different measurement methods to measure both accounting conservatism and intellectual capital and the possibility of comparing the methods and sectors may be stated as the originality of the study in the literature.

\section{DEFINITION OF ACCOUNTING CONSERVATISM AND INTELLECTUAL CAPITAL}

Accounting conservatism, which affects the accounting theory and applications, particularly the presentation and the quality of financial statements are defined as "proper reporting of the assets, liabilities, incomes and expenses based on a cautious approach to uncertainties and risks that might have impacts on the presentation of financial information, ignoring possible profits; however, always considering the possible losses, to prefer the least optimistic situation for the owners of the company" (Basu, 1997; Wang et al., 2008:2; Givoly \& Hayn, 2000:291).

Based on this definition, it is also ambiguous what high conservatism means. There are at least two interpretations, the following:
- High degree of proper reporting - as in the level of details provided in the reporting.

- High degree of caution being placed on uncertainties and risks.

It can be stated that the second interpretation is more logical. Because the essence of accounting conservatism based on caution being placed on uncertainties and risks. Therefore, the measurement methods are mentioned in this study, which express a high or low level of conservatism is only based on statistical figures (Wang 2009:19).

In the broad range of the stakeholders, from business executives to business leaders, from those that purchase goods and services, from the business to its staff, all of these parties may demand that their interests are considered superior. Stakeholders may act according to their interests from time to time in or out company. In such a situation, conflicts of interests are inevitable. However, such conflicts may be avoided with the contracts that will be made in line with the accounting conservatism. Meanwhile, reasonable requests of the parties can also be provided (Watts \& Zimmerman, 2003; Leone et al., 2006; Mashayekhi et al., 2009; Pae et al., 2005; Chandra et al., 2004).

One of the significant aspects of the studies that are conducted on accounting conservatism is that there is a great diversity among these methods measuring the accounting conservatism, and that there is no significant consistency among them. The measurement methods of accounting conservatism were used in applied studies to test the theories and hypotheses about conservatism, and the differences of these measurement methods were revealed in some applied studies that employed multiple measurement methods (Wang 2009:26). For this reason, there may be uncertainties about the validity of the results that are obtained with a certain measurement method and about the significance levels of the measurement methods. When the literature on accounting conservatism studies is reviewed, it is seen that the following five measurement methods come to the forefront (Basu, 1997; Beaver \& Ryan, 2000; Ball \& Shivakumar, 2005; Penman \& Zhang, 2002; Givoly \& Hayn, 2000). These are;

- The method of measuring the asymmetric timeliness of the earnings,

- The method of measuring the market-to-book ratio (MTB),

- The method of asymmetry of the accruals and cash flows, 
- The hidden reserves measurement method,

- The negative accruals measurement method.

The first and third of this measurement method are based on the similar basic idea of asymmetric timeliness and are estimated from models with a similar structure. Substantially, both models regress an earnings variable on a proxy for economic 'news'. Both models use dummy variables to distinguish between 'good-news' and 'bad-news'. The fundamental distinction between these two methods comes from their different choices of the proxies for economic 'news' and the response variable. The first method uses stock return as the proxy for news, whereas the third method measure uses operating cash-flow as the proxy for news (Wang, 2009:45). Other measurement methods don't use dummy variables and consider 'good-news' and 'bad-news. Its use coefficient for the measurement of accounting conservatism.

On the other hand, it is possible to define the intellectual capital, which cannot be handled easily and expressed like an ordinary intangible asset in the companies as based on the information, the process of firstly activating human resources in an enterprise to get competitive advantage and create value, and in this way, revealing intellectual assets with higher added values by emphasizing non-physical assets is used (Stewart, 1997:20; Bontis, 1998:64; Samiloglu, 2002:69; Brooking, 1997:364).

Intellectual capital, which consists of generally accepted components like human capital, structural capital, and customer capital, in one sense, needs the adoption of the business practices that are required by the industrial revolution (robot technology, cyber security, etc.). However, these business practices are extremely important, they are not adequate alone. So, enterprises need human capital for their professional workforce, structural capital for strategically important assets, and customer capital for customers, who are the reason for the existence of businesses. In this context, these business practices, and intellectual capital elements must be considered equally (Brooking, 1997; Stewart, 1997; Edvinsson \& Malone, 1997; Bontis, 1998; McElroy, 2002; Cıkrıkcı \& Dastan, 2002).

It was also emphasized in the literature that the measurement methods must have certain characteristics (being useful and meaningful, comprehensibility, etc.) to overcome the reasons that make it difficult to measure intellectual capital and to facilitate it (Erkus 2004:313). In addition, it is necessary that the measurement methods are evaluated in the context of the interests and needs of the enterprise. When all these opinions are considered, it may be argue that the methods were developed in the literature to measure intellectual capital as a whole at enterprise level and at the level of elements (Hand \& Lev, 2003:4; Carroll \& Tansey, 2000:302-303; Erkus, 2004:313).

The methods measuring intellectual capital as a whole at enterprise level make measurements in a holistic manner without focusing on the elements of intellectual capital (Stewart, 1997; Rodov \& Leliaert, 2002; Bontis, 1998; Chung \& Pruitt, 1994; Celik \& Percin, 2000). These are;

- Intellectual capital performance method (also known as the market-to-book ratio - MTB),

- Tobin's Q Rate Method,

- Calculated intangible value method.

Two approaches are adopted in methods measuring the intellectual capital at the level of elements in general (Pulic, 1998; Pulic, 2004; Ercan et al., 2003; Kim, 2004). In these methods, either an approach is adopted that go towards the whole by measuring the elements of intellectual capital one by one, or it is sufficed to measure one or more elements of intellectual capital, and the whole is not considered. These methods are;

- Value added intellectual coefficient method (VAIC),

- Economic value-added method (EVA),

- Market value added method (MVA).

Among the other measurement methods measuring the intellectual capital at the elements level, those that come to the forefront in the literature are listed below (Van den Berg, 2002; Edvinsson, 1997; Bontis, 2001; Kaplan and Norton, 1999). These are;

- Intellectual capital index measurement method,

- Skandia Guide measurement method,

- Technology broker measurement method,

- Balanced score table measurement method,

- Intangible assets list measurement method.

\section{LITERATURE REVIEW}

Despite the limited number of studies that deal with the relationship between accounting conservatism and intellectual capital directly in the literature, it is possible to argue that there are many applied studies conducted on accounting conservatism and intellectual capital issues separately and in relationship to other subjects. 
The studies conducted as of 2005 (new regulations in the field of accounting based on international accounting standards) directly or indirectly on the subject, which are considered to contribute to the analysis of this study are given in chronological order in the table below.

The aspects that make this study different from the studies in the literature;

- In this study, it is possible to state that the effect of accounting conservatism on intellectual capital was investigated to contribute the literature,
- Four different measurement methods were employed to measure both accounting conservatism and intellectual capital,

- The opportunity of making comparisons between the methods and sectors was provided,

Accounting conservatism literature is given as a summary in Table 1 as authors, years, subjects and scopes, measurement methods, and findings.

Table 1: Summary of accounting conservatism literature

\begin{tabular}{|c|c|c|c|c|}
\hline Author(s) & Year & Subject and Scope & $\begin{array}{l}\text { Measurement } \\
\text { Method(s) }\end{array}$ & Finding(s) \\
\hline Pae et al. & 2005 & $\begin{array}{l}\text { The relationship between accounting } \\
\text { conservatism and market-to-book ratio. } \\
\text { USA Enterprises. 1970-2001. }\end{array}$ & $\begin{array}{l}\text { Basu (1997), } \\
\text { Beaver-Ryan } \\
(2000)\end{array}$ & $\begin{array}{l}\text { It was reported that there is a negative } \\
\text { relationship between accounting } \\
\text { conservatism and market-to-book ratio. }\end{array}$ \\
\hline Cheng & 2005 & $\begin{array}{l}\text { The relationship between accounting } \\
\text { conservatism and return on equity (ROE). } \\
\text { The enterprises between } 6000 \text { and } 6999 \text { in } \\
\text { Standard Industry Encoding. } 1976-1997 \text {. }\end{array}$ & $\begin{array}{l}\text { Penman-Zhang } \\
\text { (2002) }\end{array}$ & $\begin{array}{l}\text { It was shared as a finding that the return } \\
\text { on equity was higher in businesses, } \\
\text { which applied conservative accounting } \\
\text { policies predominantly. }\end{array}$ \\
\hline $\begin{array}{l}\text { Ahmed } \\
\text { and } \\
\text { Duelman }\end{array}$ & 2007 & $\begin{array}{l}\text { The relationship between corporate } \\
\text { management and accounting } \\
\text { conservatism. S\&P } 1500 \text { Enterprises. 1999- } \\
2001 \text {. }\end{array}$ & $\begin{array}{l}\text { Basu (1997), } \\
\text { Beaver-Ryan } \\
\text { (2000), Givoly } \\
\text { Hayn (2000) }\end{array}$ & $\begin{array}{l}\text { It was determined that accounting } \\
\text { conservatism was related negatively } \\
\text { with the internal management of an } \\
\text { enterprise, and was positively related } \\
\text { with the external stakeholders. }\end{array}$ \\
\hline Krishnan & 2007 & $\begin{array}{l}\text { The relationship between auditing } \\
\text { and auditor quality and accounting } \\
\text { conservatism. The enterprises in the USA. } \\
\text { 2001-2002. }\end{array}$ & Basu (1997) & $\begin{array}{l}\text { Following the collapse of the audit firm } \\
\text { that was named Arthur Andersen, it was } \\
\text { found that this company considered } \\
\text { conservative accounting policies to be } \\
\text { more important to decrease the court } \\
\text { costs of its former clients. }\end{array}$ \\
\hline Qiang & 2007 & $\begin{array}{l}\text { The relationship between accounting } \\
\text { conservatism and some variables } \\
\text { (contracts, court expenses, taxes, and } \\
\text { political factors). The enterprises in the } \\
\text { USA. 1982-2002. }\end{array}$ & $\begin{array}{l}\text { Beaver-Ryan } \\
\text { (2000), Givoly- } \\
\text { Hayn (2000) }\end{array}$ & $\begin{array}{l}\text { It was shared as a finding that several } \\
\text { variables encouraged businesses } \\
\text { to conditional and non-conditional } \\
\text { conservatism, and there was a negative } \\
\text { relationship between accounting } \\
\text { conservatism and market-to-book ratio. }\end{array}$ \\
\hline $\begin{array}{l}\text { LaFond } \\
\text { and Watts }\end{array}$ & 2008 & $\begin{array}{l}\text { The relationship between information } \\
\text { asymmetry and accounting conservatism. } \\
\text { The enterprises in the USA stock market. } \\
\text { 1983-2001. }\end{array}$ & Basu (1997) & $\begin{array}{l}\text { It was determined that accounting } \\
\text { conservatism increased information } \\
\text { asymmetry. }\end{array}$ \\
\hline Lara et al. & 2009 & $\begin{array}{l}\text { The relationship between corporate } \\
\text { management and accounting } \\
\text { conservatism. The companies in the USA. } \\
\text { 1992-2003. }\end{array}$ & $\begin{array}{l}\text { Basu } \\
\text { (1997), Ball- } \\
\text { Shivakumar } \\
\text { (2005), Givoly- } \\
\text { Hayn (2000) }\end{array}$ & $\begin{array}{l}\text { It was determined that there is } \\
\text { a positive relationship between } \\
\text { accounting conservatism and corporate } \\
\text { management. }\end{array}$ \\
\hline $\begin{array}{l}\text { Sofian et } \\
\text { al. }\end{array}$ & 2011 & $\begin{array}{l}\text { The relationship between the intellectual } \\
\text { capital on conservatism and value } \\
\text { relevance of earnings. }\end{array}$ & $\begin{array}{l}\text { Literature } \\
\text { review }\end{array}$ & $\begin{array}{l}\text { It was shared as a finding that generally } \\
\text { accepted accounting principles, } \\
\text { accounting standards, and accounting } \\
\text { conservatism prevented intellectual } \\
\text { capital to come to the forefront. }\end{array}$ \\
\hline
\end{tabular}


Table 1: Continue

\begin{tabular}{|c|c|c|c|c|}
\hline Author(s) & Year & Subject and Scope & $\begin{array}{l}\text { Measurement } \\
\text { Method(s) }\end{array}$ & Finding(s) \\
\hline Gokmen & 2012 & $\begin{array}{l}\text { The relationship between the value } \\
\text { relevance of earnings and accounting } \\
\text { conservatism. } 106 \text { manufacturing } \\
\text { companies. } 2006-2010 \text {. }\end{array}$ & Basu (1997) & $\begin{array}{l}\text { It was reported that accounting } \\
\text { conservatism has a negative effect on the } \\
\text { value relevance of earnings. }\end{array}$ \\
\hline $\begin{array}{l}\text { Francis } \\
\text { et al. }\end{array}$ & 2013 & $\begin{array}{l}\text { The relationship between the financial } \\
\text { crises and accounting conservatism. S\&P } \\
1500 \text { companies. } 2007-2009 \text {. }\end{array}$ & $\begin{array}{l}\text { Basu (1997), } \\
\text { Penman-Zhang } \\
(2002)\end{array}$ & $\begin{array}{l}\text { It was shared as a finding that the } \\
\text { enterprises with higher conservatism } \\
\text { levels before financial crises lost less value } \\
\text { in crises compared to the enterprises with } \\
\text { lower conservatism levels. }\end{array}$ \\
\hline Crawley & 2015 & $\begin{array}{l}\text { The effect of accounting conservatism } \\
\text { on macroeconomic indicators. S\&P } 500 \\
\text { companies. 1955-2007. }\end{array}$ & Other & $\begin{array}{l}\text { It was shared as a finding that accounting } \\
\text { conservatism might affect the basic } \\
\text { macroeconomic indicators like Gross } \\
\text { National Product (GNP) and Consumer } \\
\text { Price Index (CPI). }\end{array}$ \\
\hline $\begin{array}{l}\text { Ettredge } \\
\text { et al. }\end{array}$ & 2016 & $\begin{array}{l}\text { The relationship between commercial } \\
\text { cases against companies and accounting } \\
\text { conservatism. The companies in the USA. } \\
\text { 1996-2011. }\end{array}$ & Basu (1997) & $\begin{array}{l}\text { It was reported that as the accounting } \\
\text { conservatism levels of the enterprises } \\
\text { increased, the commercial cases against } \\
\text { the enterprise ended in favor of the } \\
\text { enterprise. }\end{array}$ \\
\hline Sana'a NM & 2016 & $\begin{array}{l}\text { The effect of accounting conservatism } \\
\text { on financial performance indicators. } \\
\text { Insurance companies in Jordan 2007-2014. }\end{array}$ & $\begin{array}{l}\text { Givoly-Hayn } \\
(2000)\end{array}$ & $\begin{array}{l}\text { It was reported that accounting } \\
\text { conservatism has a positive effect on } \\
\text { financial performance indicators. }\end{array}$ \\
\hline Polat & 2016 & $\begin{array}{l}\text { The relationship between corporate } \\
\text { management and accounting } \\
\text { conservatism. The companies in Borsa } \\
\text { Istanbul (BIST) } 100 \text { Index 2006-2013. }\end{array}$ & $\begin{array}{l}\text { Ball- } \\
\text { Shivakumar } \\
(2005)\end{array}$ & $\begin{array}{l}\text { It was reported that there is a positive } \\
\text { relationship between corporate } \\
\text { management and accounting } \\
\text { conservatism. }\end{array}$ \\
\hline Ge et al. & 2018 & $\begin{array}{l}\text { The relationship between investor } \\
\text { sentiment and accounting conservatism. } \\
\text { The companies in the USA. 1987-2008. }\end{array}$ & $\begin{array}{l}\text { Re-edited, Ball- } \\
\text { Shivakumar } \\
(2005)\end{array}$ & $\begin{array}{l}\text { Investors had higher sensitivity for } \\
\text { making investments as a result of their } \\
\text { earlier consideration of economic losses } \\
\text { due to conservatism. }\end{array}$ \\
\hline Li and Xu & 2018 & $\begin{array}{l}\text { The relationship between asset specificity } \\
\text { and accounting conservatism. The } \\
\text { companies in the USA. 1988- } 2011 \text {. }\end{array}$ & Basu (1997) & $\begin{array}{l}\text { It was reported that asset specificity } \\
\text { affected the current value, risk of } \\
\text { bankruptcy, cash flows directly; however, } \\
\text { there was a negative relationship } \\
\text { between accounting conservatism and } \\
\text { asset specificity. }\end{array}$ \\
\hline Chen & 2019 & $\begin{array}{l}\text { The relationship between the success } \\
\text { of family enterprises and accounting } \\
\text { conservatism. The companies in Japan. } \\
2011-2016 .\end{array}$ & Basu (1997) & $\begin{array}{l}\text { It was reported that the success of family } \\
\text { enterprises will improve accounting } \\
\text { conservatism. }\end{array}$ \\
\hline
\end{tabular}

Similarly, the summary of the intellectual capital literature is given in Table 2 in the form of the authors, years, subjects, measurement methods and findings. 
Table 2: Summary of intellectual capital literature

\begin{tabular}{|c|c|c|c|c|}
\hline Author(s) & Year & Subject and Scope & Measurement Method(s) & Finding(s) \\
\hline Chen et al. & 2005 & $\begin{array}{l}\text { The relationship between } \\
\text { intellectual capital and } \\
\text { market values of the } \\
\text { enterprises and financial } \\
\text { performances. The companies } \\
\text { in Taiwan stock exchange. } \\
\text { 1975-1991. }\end{array}$ & $\begin{array}{l}\text { Value added intellectual } \\
\text { coefficient (VAIC) }\end{array}$ & $\begin{array}{l}\text { It was shared as a finding that } \\
\text { intellectual capitals of enterprises } \\
\text { had positive effect on financial } \\
\text { performances, and that intellectual } \\
\text { capital might be a sign for the } \\
\text { future financial performance of the } \\
\text { enterprise. }\end{array}$ \\
\hline Yalama & 2005 & $\begin{array}{l}\text { The relationship between } \\
\text { intellectual capital and } \\
\text { profitability. The companies } \\
\text { in banking sector. 1995-2004. }\end{array}$ & $\begin{array}{l}\text { Value added intellectual } \\
\text { coefficient (VAIC) }\end{array}$ & $\begin{array}{l}\text { It was shared as a finding that the } \\
\text { ability of businesses that can make } \\
\text { profits from intellectual assets was at } \\
\text { medium level. }\end{array}$ \\
\hline Akmese & 2006 & $\begin{array}{l}\text { The relationship between } \\
\text { Intellectual capital and } \\
\text { company value. } 35 \\
\text { companies in Borsa Istanbul } \\
\text { (BIST) from various sectors. }\end{array}$ & $\begin{array}{l}\text { Intellectual capital } \\
\text { performance (market-to- } \\
\text { book ratio) }\end{array}$ & $\begin{array}{l}\text { It was shared as a finding that the } \\
\text { structural capital element of the } \\
\text { intellectual capital was influential on } \\
\text { market-to-book ratio of enterprises. }\end{array}$ \\
\hline Kamath & 2008 & $\begin{array}{l}\text { The relationship between } \\
\text { intellectual capital and } \\
\text { profitability. The drug } \\
\text { companies in India. 1996- } \\
2006 .\end{array}$ & $\begin{array}{l}\text { Value added intellectual } \\
\text { coefficient (VAIC) }\end{array}$ & $\begin{array}{l}\text { It was reported that the effect with } \\
\text { the biggest impact on the profitability } \\
\text { and productivity of the enterprise } \\
\text { among the intellectual capital } \\
\text { elements was the human capital. }\end{array}$ \\
\hline Unal & 2010 & $\begin{array}{l}\text { Intellectual capital and } \\
\text { accounting standards. }\end{array}$ & Literature review & $\begin{array}{l}\text { It was determined that intangible } \\
\text { fixed assets were quite inadequate in } \\
\text { expressing intellectual capital. }\end{array}$ \\
\hline $\begin{array}{l}\text { Zor and } \\
\text { Cengiz }\end{array}$ & 2013 & $\begin{array}{l}\text { The relationship between } \\
\text { intellectual capital and } \\
\text { company value. The } \\
\text { companies of Energy Sector } \\
\text { in Borsa Istanbul (BIST) } \\
\text { 2009-2011. }\end{array}$ & $\begin{array}{l}\text { Intellectual capital } \\
\text { performance (market-to- } \\
\text { book ratio) }\end{array}$ & $\begin{array}{l}\text { It was determined that enterprises } \\
\text { do not care about intellectual } \\
\text { capital, and only tangible fixed assets } \\
\text { were influential on the value of the } \\
\text { enterprise. }\end{array}$ \\
\hline $\begin{array}{l}\text { Bayraktaroglu } \\
\text { et al. }\end{array}$ & 2014 & $\begin{array}{l}\text { The relationship between } \\
\text { intellectual capital usage } \\
\text { efficacy and market } \\
\text { performance. The companies } \\
\text { in Chemistry, Petroleum, } \\
\text { and Plastic Sector in Borsa } \\
\text { Istanbul (BIST).2006-2012. }\end{array}$ & $\begin{array}{l}\text { Value added intellectual } \\
\text { coefficient (VAIC) }\end{array}$ & $\begin{array}{l}\text { It was determined that a significant } \\
\text { difference was not detected between } \\
\text { intellectual capital use efficacy and } \\
\text { market performance. }\end{array}$ \\
\hline $\begin{array}{l}\text { Kendirli and } \\
\text { Diker }\end{array}$ & 2016 & $\begin{array}{l}\text { The effect of intellectual } \\
\text { capital on financial } \\
\text { performance indicators. } \\
\text { Seven companies in paper } \\
\text { and wrapping industry. 2011- } \\
2013\end{array}$ & $\begin{array}{l}\text { Intellectual capital } \\
\text { performance (market-to- } \\
\text { book ratio), Economic value } \\
\text { added (EVA), Calculated } \\
\text { intangible value }\end{array}$ & $\begin{array}{l}\text { It was reported that intellectual } \\
\text { capital affect financial performance. }\end{array}$ \\
\hline Hussunki et al. & 2017 & $\begin{array}{l}\text { The relationship between } \\
\text { intellectual capital and } \\
\text { information management } \\
\text { applications and business } \\
\text { performance. The companies } \\
\text { in Finland. }\end{array}$ & $\begin{array}{l}\text { Intellectual capital and } \\
\text { information management } \\
\text { practices }\end{array}$ & $\begin{array}{l}\text { It was reported that the enterprises } \\
\text { that had different intellectual capital } \\
\text { levels did not have any differences in } \\
\text { terms of information management } \\
\text { use. }\end{array}$ \\
\hline Ozkan et al. & 2017 & $\begin{array}{l}\text { The relationship between } \\
\text { intellectual capital and } \\
\text { financial performance. The } 44 \\
\text { banking companies in Turkey. } \\
\text { 2005-2014. }\end{array}$ & $\begin{array}{l}\text { Value added intellectual } \\
\text { coefficient (VAIC) }\end{array}$ & $\begin{array}{l}\text { It was shared as a finding that the } \\
\text { usage efficacy of intellectual capital } \\
\text { and human capital affect financial } \\
\text { performance in a positive way. }\end{array}$ \\
\hline
\end{tabular}


Table 2: Continue

\begin{tabular}{lllll}
\hline Author(s) & Year & Subject and Scope & Measurement Method(s) & Finding(s) \\
\hline $\begin{array}{l}\text { Cenciarelli } \\
\text { et al. }\end{array}$ & 2018 & $\begin{array}{l}\text { The relationship between } \\
\text { intellectual capital and } \\
\text { bankruptcy risk. The } \\
\text { companies in the USA. 1985- } \\
\text { 2015. }\end{array}$ & $\begin{array}{l}\text { Value added intellectual } \\
\text { coefficient (VAIC) }\end{array}$ & $\begin{array}{l}\text { It was shared as a finding that } \\
\text { intellectual capital was better in } \\
\text { estimating the bankruptcy risk when } \\
\text { compared to the other estimation } \\
\text { methods. }\end{array}$ \\
\hline $\begin{array}{llll}\text { Bayraktaroglu } \\
\text { et al. }\end{array}$ & 2019 & $\begin{array}{l}\text { The relationship between } \\
\text { intellectual capital and } \\
\text { firm performance. Turkish } \\
\text { manufacturing firms. 2003- } \\
2013\end{array}$ & $\begin{array}{l}\text { Extended Value-added } \\
\text { intellectual coefficient } \\
\text { (VAIC) }\end{array}$ & $\begin{array}{l}\text { It has been detected that innovation } \\
\text { capital effectiveness has a direct } \\
\text { impact on firms' productivity. But } \\
\text { intellectual capital effectiveness } \\
\text { elements have a moderating role } \\
\text { on the relationship between capital } \\
\text { employed efficiency and profitability. }\end{array}$ \\
\hline
\end{tabular}

If a general assessment is to be made about the literature in Table 1 and 2, it is noteworthy that there is only one study that addresses the relationship between accounting conservatism and intellectual capital directly (Sofian et al., 2011), and this study was not conducted at empirical level. It is also possible to share as a finding that there are only a limited number of indirect studies among the 30 studies that were examined in the accounting conservatism literature. Only 5 studies employed more than two measurement methods, and only one study used more than one measurement method among the 18 studies in the intellectual capital literature, and that only the literature review was used to make conclusions in some studies. Furthermore, no cross-sector comparisons were made in the studies.

\section{METHODOLOGY}

\section{The Purpose, Method and Scope of the Study}

The aim of the study is to investigate the impact of accounting conservatism on intellectual capital. The method that was used to achieve this purpose was as follows:

- Determining how the accounting conservatism and intellectual capital data were calculated for each of the 38 manufacturing industry and 31 financial institutions companies in Borsa Istanbul (BIST) 100 Index in Turkey between 2006 and 2017,

- Creating eight panel datasets for four different measurement methods (the asymmetric timeliness of the earnings, market-to-book ratio, asymmetry of the accruals and cash flows, hidden reserves and negative accruals) and two sectors with the help of the data calculated in this respect,
- Determining the conservatism levels of the companies in general with the help of the panel datasets created, and then, investigating the possible effect of accounting conservatism on intellectual capital.

The scope of the study consists of the companies of 38 manufacturing industry and 31 financial institutions in BIST 100 Index, which constitute the basic companies in Borsa Istanbul (BIST) in Turkey. In this context, it was planned to include all the companies in the index in the scope of the study. However, it was not possible to include all these companies in the index to create balanced panels for the purpose of obtaining more accurate results in the panel data analysis for the period between 2006 and 2017, which was included in the analysis. In this respect, the companies of 36 manufacturing industry and 26 financial institutions whose data were accessed in a continuous way in three measurement methods of accounting conservatism were included in the analyses, and 432 (manufacturing industry) - 312 (financial institutions) observations were obtained. However, in "the asymmetric timeliness of earnings method", the companies of 33 manufacturing industry and 23 financial institutions whose data were accessed in a continuous way were analysed, and in this way, 396 (manufacturing industry) - 276 (financial institutions) observations were obtained. While the data of these companies were obtained, the panel datasets were created by accessing the financial statements, footnotes of their financial statements, and the share data of these companies in various financial sites (like Bloomberg ht, invest.com).

\section{The Hypotheses and Model of the Study}

Eight different hypotheses were developmented in the scope of this study in Table 3. 
The study models and the regression equations of these models are shown in Table 4. Models and the regression equations are valid for both sectors.

In these study models;

- $a_{i t}$ : Refers to the constant coefficients of the models,

Table 3: Research hypotheses

\section{Hypotheses}

$\mathrm{H}_{1} \quad$ Accounting conservatism, which is measured according to the Asymmetric Timeliness of Earnings Measurement Method, has an effect on intellectual capital in manufacturing industry.

$\mathrm{H}_{2}$ Accounting conservatism, which is measured according to the Asymmetric Timeliness of Earnings Measurement Method, has an effect on intellectual capital in financial institutions.

$\mathrm{H}_{3} \quad$ Accounting conservatism, which is measured according to the Asymmetry of Accruals and Cash Flows, has an effect on intellectual capital in manufacturing industry.

$\mathrm{H}_{4} \quad$ Accounting conservatism, which is measured according to the Asymmetry of Accruals and Cash Flows, has an effect on intellectual capital in financial institutions.

$\mathrm{H}_{5} \quad$ Accounting conservatism, which is measured with the market-to-book ratio Measurement Method has an effect on intellectual capital in manufacturing industry.

$\mathrm{H}_{6} \quad$ Accounting conservatism, which is measured with the market-to-book ratio Measurement Method has an effect on intellectual capital in financial institutions.

$\mathrm{H}_{7}$ Accounting conservatism, which is measured according to the Negative Accruals Measurement Method, has an effect on the intellectual capital in manufacturing industry.

$\mathrm{H}_{8}$ Accounting conservatism, which is measured according to the Negative Accruals Measurement Method, has an effect on the intellectual capital in financial institutions.

Table 4: Study models

Basu (1997) Model

Ball and Shivakumar (2005) Model

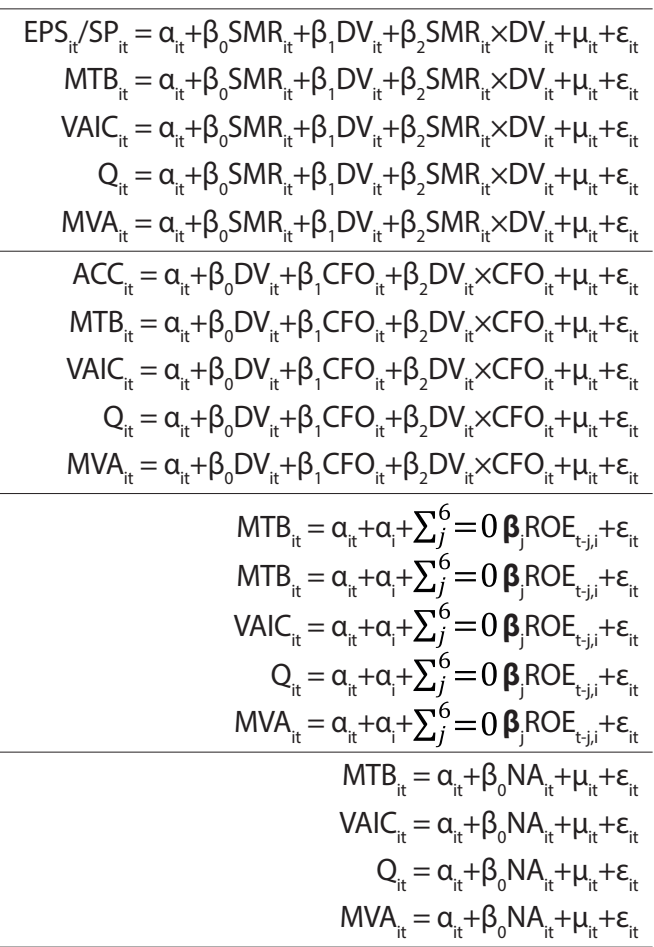

Beaver and Ryan (2000) Model

Givoly and Hayn (2000) Model
- $a_{\text {: }}$ Refers to the inclination component (bias) of the model (constant effects coefficient),

$\beta_{0^{\prime}} \beta_{1^{\prime}} \beta_{2}$ and $\beta_{\mathrm{j}}$ : Refers to the coefficients in the

$\mu_{i t}$ : Refers to the error term components in the models according to unit or time,

- $\varepsilon_{\mathrm{it}}$ : Refers to the error terms of the models. 
Table 5: Variables in Study Models

\begin{tabular}{lll}
\hline Abbreviation for Variable & Explanation of the variable & Source of the Variable \\
\hline EPS & Earnings Per Share & Financial Statement and Income Statement \\
\hline SP & Stock Price & Various finacial websites (bloomberg ht, invest.com etc.) \\
\hline SMR & Stock Market Return & Finacial Statement Footnotes, various financial websites \\
\hline DV & Dummy Variable & It is determined according to the stock market return. \\
\hline ACC & Activity Accruals & Financial Statement and footnotes, Income Statement \\
\hline CFO & Cash Flow Operations & Cash Flow Statement \\
\hline DV & Dummy Variable & It is determined according to the CFO \\
\hline MTB & Market to Book Ratio & Financial Statement Footnotes, various financial websites \\
\hline ROE & Return on Equity & Financial Statement and Income Statement \\
\hline NA & Negative Accruals & Financial Statement and footnotes, Income Statement \\
\hline VAIC & Value Added Intellectual Capital & Financial Statement and footnotes, Income Statement \\
\hline Q & Approximate Tobin Q Ratio & Financial Statement, Income Statement, financial websites \\
\hline MVA & Market Value Added & Financial Statement and Income Statement \\
\hline
\end{tabular}

\section{Study Findings and Evaluation of This Findings}

The descriptive statistics of the variables that were included in the study and the information on their interpretations are given in Table 6. Particularly, when the results related to the dependent variables and the variables that represent the intellectual capital are examined in the descriptive statistics, EPS/SP variable is between $-2,8996$ and 5,6790, and its mean was 0,1727 in manufacturing industry. EPS/SP variable is between $-1,7079$ and 8,2976 , and its mean was 0,1578 in financial institutions. On the other hand, The ACC variable is between $-3644,9420$ and 3407,4500 and its mean was $-101,7934$ in manufacturing industry.
Unlike the manufacturing industry, ACC variable is mean 34,5526 in the financial institutions. During the observation period, the NA variable, which represents the accounting conservatism degree, had a minimum value of $-331,4145$ and $-302,8678$ in both sectors. When the MTB, VAIC, Q and MVA variables, which represent intellectual capital values, firstly they are 5,4135; 19,7559; 19,$0570 ; 211,7976$ in manufacturing industry, secondly, they are 1,$2447 ; 20,4068 ; 0,6171 ; 124,1824$ in financial institutions. The results are same in other methods for the intellectual capital values. When the fact that these values are positive and high is considered, it can be argued that the companies have intellectual assets and intellectual capital.

Table 6: Descriptive statistics

\begin{tabular}{|c|c|c|c|c|c|c|c|c|c|c|c|}
\hline Variables & $\begin{array}{c}\text { Number of } \\
\text { Observation } \\
\text { s }\end{array}$ & Mean & $\begin{array}{l}\text { Standard } \\
\text { Deviation }\end{array}$ & $\begin{array}{r}\text { Minimum } \\
\text { Value }\end{array}$ & $\begin{array}{r}\text { Maximum } \\
\text { Value }\end{array}$ & Variables & $\begin{array}{c}\text { Number of } \\
\text { Observation } \\
\text { s } \\
\end{array}$ & Mean & $\begin{array}{l}\text { Standard } \\
\text { Deviation }\end{array}$ & $\begin{array}{r}\text { Minimum } \\
\text { Value }\end{array}$ & $\begin{array}{r}\text { Maximum } \\
\text { Value }\end{array}$ \\
\hline EPS/SP & $396(\mathrm{M})$ & 0,1727 & 0,6487 & $-2,8996$ & 5,6790 & ACC & $312(\mathrm{~F})$ & 34,5526 & 428,8567 & $-615,9528$ & 2858,8410 \\
\hline SMR & $396(\mathrm{M})$ & 0,3492 & 0,8214 & $-0,7857$ & 5,1390 & DV & $312(\mathrm{~F})$ & 0,2532 & 0,4355 & 0 & 1 \\
\hline DV & 396 (M) & 0,3485 & 0,4771 & 0 & 1 & $\mathrm{CFO}$ & $312(\mathrm{~F})$ & 37,3771 & 210,1822 & $-1156,4180$ & 2070,8160 \\
\hline $\mathrm{SMR} \times \mathrm{DV}$ & $396(\mathrm{M})$ & $-0,1011$ & 0,1851 & 0,7857 & 0 & $\mathrm{DV} \times \mathrm{CFO}$ & $312(\mathrm{~F})$ & $-18,3126$ & 100,9104 & $-1156,4180$ & 0 \\
\hline MTB & $396(\mathrm{M})$ & 5,4135 & 21,5449 & $-23,1786$ & 173,1202 & MTB & $312(\mathrm{~F})$ & 1,2557 & 1,8505 & $-3,2556$ & 26,6815 \\
\hline VAIC & 396 (M) & 19,7559 & 39,3417 & $-56,7568$ & 356,2007 & VAIC & $312(\mathrm{~F})$ & 19,3653 & 31,1677 & $-3,8713$ & 233,2028 \\
\hline Q & $396(\mathrm{M})$ & 19,0570 & 98,8751 & $-0,6031$ & 847,1846 & Q & $312(\mathrm{~F})$ & 0,5961 & 0,8179 & $-0,1890$ & 10,8252 \\
\hline MVA & $396(\mathrm{M})$ & 211,7976 & 549,8369 & $-1538,6200$ & 3732,1550 & MVA & $312(\mathrm{~F})$ & 157,0399 & 410,2539 & $-2805,2840$ & 2129,0620 \\
\hline EPS/SP & $276(F)$ & 0,1578 & 0,6234 & $-1,7097$ & 8,2976 & ROE & $432(\mathrm{M})$ & 0,1494 & 0,4795 & $-4,4584$ & 7,5724 \\
\hline SMR & $276(F)$ & 0,2954 & 0,6466 & $-0,7438$ & 3,8482 & MTB & $432(\mathrm{M})$ & 5,1708 & 20,6759 & $-23,1786$ & 173,1202 \\
\hline DV & $276(F)$ & 0,3623 & 0,4815 & 0 & 1 & VAIC & $432(\mathrm{M})$ & 25,9286 & 70,1472 & $-56,7568$ & 1056,5730 \\
\hline $\mathrm{SMR} \times \mathrm{DV}$ & $276(F)$ & $-0,0915$ & 0,1651 & $-0,7438$ & 0 & Q & $432(\mathrm{M})$ & 23,0172 & 101,4606 & $-0,6031$ & 847,1846 \\
\hline MTB & $276(F)$ & 1,2447 & 1,9475 & $-3,2556$ & 26,6815 & MVA & $432(\mathrm{M})$ & 218,5785 & 544,9767 & $-1538,6200$ & 3732,1550 \\
\hline VAIC & $276(F)$ & 20,4068 & 32,8430 & $-3,8713$ & 233,2028 & ROE & $312(\mathrm{~F})$ & 0,0774 & 1,0608 & $-17,9678$ & 3,4048 \\
\hline Q & $276(\mathrm{~F})$ & 0,6171 & 0,8564 & $-0,1890$ & 10,8252 & MTB & $312(\mathrm{~F})$ & 1,2557 & 1,8505 & $-3,2556$ & 26,6815 \\
\hline MVA & $276(F)$ & 124,1824 & 383,7392 & $-2805,2840$ & 2129,0620 & VAIC & $312(F)$ & 19,3653 & 31,1677 & $-3,8713$ & 233,2028 \\
\hline ACC & $432(\mathrm{M})$ & $-101,7934$ & 695,6485 & $-3644,9420$ & 3407,4500 & Q & $312(F)$ & 0,5961 & 0,8179 & $-0,1890$ & 10,8252 \\
\hline DV & $432(\mathrm{M})$ & 0,2222 & 0,4162 & 0 & 1 & MVA & $312(\mathrm{~F})$ & 157,0399 & 410,2539 & $-2805,2840$ & 2129,0620 \\
\hline CFO & $432(\mathrm{M})$ & 45,0128 & 149,6570 & $-556,6716$ & 1099,9990 & \multirow{6}{*}{\multicolumn{6}{|c|}{ M: Manufacturing Industry, F: Financial Institutions }} \\
\hline $\mathrm{DV} \times \mathrm{CFO}$ & $432(\mathrm{M})$ & $-8,5373$ & 49,4637 & $-556,6716$ & 0 & & & & & & \\
\hline MTB & $432(\mathrm{M})$ & 5,1708 & 20,6759 & $-23,1786$ & 173,1202 & & & & & & \\
\hline VAIC & $432(\mathrm{M})$ & 25,9286 & 70,1472 & $-56,7568$ & 1056,5730 & & & & & & \\
\hline Q & $432(\mathrm{M})$ & 23,0172 & 101,4606 & $-0,6031$ & 847,1846 & & & & & & \\
\hline MVA & 432 (M) & 218,5785 & 544,9767 & $-1538,6200$ & 3732,1550 & & & & & & \\
\hline
\end{tabular}




\section{The Effect of Asymmetric Timeliness of Earnings Measurement Method on Intellectual Capital}

When the estimation process is performed based on the Basu model (1997) in the manufacturing industry, it is understood from the cross-sectional and time $\mathrm{F}$ values in Table 7 and the Hausman tests that when the dependent variable is EPS/SP (the Rate of Earning Per Share to Stock Price), the unit and time-effective fixed effects model is valid; when the dependent variable is VAIC (Value Added Intellectual Coefficient), the unit and time-effective random effects model is valid; and when dependent variables are market-to-book ratio, Q (Approximate Tobin Q Rate) and MVA (Market Value Added), the unit-effective random effects model is valid.

According to Basu (1997)'s measurement method, it is possible to argue that the greater the asymmetric earning, the higher the accounting conservatism. For companies that have positive Stock Market Return (SMR), when the Dummy Variable (DV) is taken as "0", the effect of SMR on the dependent variable EPS/SP $(0.2419-0=0.2419)$ is positive. When the DV is taken " 1 " for enterprises that have negative SMR, the effect of SMR on the dependent variable $(0.2419-0.0395=0.2024)$ is positive again. In other words, there is no asymmetry if the news is good and bad. According to the method of asymmetric timeliness measurement of the earnings, it may be argued that the companies have slight conservative accounting policies (due to the partial differences between the coefficients) according to the coefficient of the interaction component (SMR $\times D V$ ) variable $(0,0395)$ expressing the accounting conservatism.

In addition, in case the dependent variable is selected as MVA, it can be understood in Table 7 that the $S M R \times D V$ interaction component representing accounting conservatism has a positive effect on intellectual capital. In other words, as the level of conservatism of enterprises increases, the intellectual capitals of them will also increase. For this reason, it can be argued that accounting conservatism that is measured according to the method of asymmetric timeliness of the earning has a positive effect on intellectual capital according to a dependent variable (MVA). In this context, the $H_{1}$ hypothesis will be accepted for this variable. In some of the studies in the literature, we may have the opportunity of making a comparison between accounting conservatism and Intellectual Capital Performance (ICP) (also known as the market-to-book ratio), since they are investigated in relationship to each other. This is also valid for the other hypotheses discussed in the study. For this reason, the results obtained in the studies conducted by Sana'a NM (2016), Chen et al. (2005) and Akmeşe (2006)

Table 7: The analysis results of the Basu (1997) Model in the manufacturing industry

\begin{tabular}{|c|c|c|c|c|c|}
\hline Variables & EPS/SP & МTB(ICP) & VAIC & $\mathbf{Q}$ & MVA \\
\hline CONSTANT & $\begin{array}{c}0,0493 \\
(0,0444) \\
\end{array}$ & $\begin{array}{c}5,5852 \\
(4,0165) \\
\end{array}$ & $\begin{array}{l}16,3211^{\mathrm{a}} \\
(2,5493)\end{array}$ & $\begin{array}{c}24,3405 \\
(20,4054) \\
\end{array}$ & $\begin{array}{c}284,7898^{\mathrm{a}} \\
(101,4972) \\
\end{array}$ \\
\hline DV & $\begin{array}{c}0,1231^{\mathrm{b}} \\
(0,0514)\end{array}$ & $\begin{array}{c}-0,3348 \\
(1,0027)\end{array}$ & $\begin{array}{c}6,3152 \\
(6,1456)\end{array}$ & $\begin{array}{c}-2,0718 \\
(1,9564)\end{array}$ & $\begin{array}{c}-81,8934 \\
(57,4082) \\
\end{array}$ \\
\hline SMR & $\begin{array}{r}0,2419^{\mathrm{a}} \\
(0,0635) \\
\end{array}$ & $\begin{array}{c}0,2611 \\
(0,5086) \\
\end{array}$ & $\begin{array}{c}4,7411 \\
(5,1870) \\
\end{array}$ & $\begin{array}{c}-2,7966 \\
(2,7377) \\
\end{array}$ & $\begin{array}{l}-48,4596^{c} \\
(28,3692)\end{array}$ \\
\hline $\mathbf{S M R} \times \mathbf{D V}$ & $\begin{array}{c}0,0395^{\mathrm{a}} \\
(0,1428)\end{array}$ & $\begin{array}{c}1,4456 \\
(2,1307) \\
\end{array}$ & $\begin{array}{c}4,1657 \\
(9,3618) \\
\end{array}$ & $\begin{array}{c}35,4468 \\
(30,4142)\end{array}$ & $\begin{array}{r}272,2382^{\mathrm{a}} \\
(102,8854)\end{array}$ \\
\hline $\mathbf{R}^{2}$ & 0,0914 & 0,0673 & 0,0102 & 0,0208 & 0,0343 \\
\hline $\mathbf{F}$ & $10,28^{\mathrm{a}}$ & 4,00 & 1,58 & 2,67 & $11,98^{\mathrm{a}}$ \\
\hline $\begin{array}{l}\text { Cross- } \\
\text { Sectional F }\end{array}$ & $\begin{array}{c}3,63 \\
(0,00)\end{array}$ & $\begin{array}{r}786,35 \\
(0,00) \\
\end{array}$ & $\begin{array}{l}97,35 \\
(0,00)\end{array}$ & $\begin{array}{r}524,57 \\
(0,00) \\
\end{array}$ & $\begin{array}{r}244,07 \\
(0,00) \\
\end{array}$ \\
\hline Time F & $\begin{array}{c}1,83 \\
(0,05)\end{array}$ & $\begin{array}{c}0,00 \\
(1,00)\end{array}$ & $\begin{array}{c}6,70 \\
(0,00) \\
\end{array}$ & $\begin{array}{c}0,00 \\
(1,00)\end{array}$ & $\begin{array}{c}1,19 \\
(0,14) \\
\end{array}$ \\
\hline Hausman & $\begin{array}{l}20,92 \\
(0,00)\end{array}$ & $\begin{array}{c}0,27 \\
(0,97)\end{array}$ & $\begin{array}{c}0,91 \\
(0,82)\end{array}$ & $\begin{array}{c}1,67 \\
(0,64)\end{array}$ & $\begin{array}{c}0,91 \\
(0,82)\end{array}$ \\
\hline Wald Test & $\begin{array}{c}2,1 \mathrm{e}+05 \\
(0,00) \\
\end{array}$ & $\begin{array}{l}15,61 \\
(0,00) \\
\end{array}$ & $\begin{array}{l}15,62 \\
(0,00) \\
\end{array}$ & $\begin{array}{l}37,05 \\
(0,00) \\
\end{array}$ & $\begin{array}{l}15,61 \\
(0,00)\end{array}$ \\
\hline $\begin{array}{l}\text { Bharvaga } \\
\text { Durbin } \\
\text { Watson }\end{array}$ & 1,8874 & 1,4619 & 0,3799 & 0,5886 & 0,5435 \\
\hline $\begin{array}{l}\text { Baltagi Wu } \\
\text { LBI }\end{array}$ & 1,9874 & 1,7165 & 0,6324 & 0,7563 & 1,0042 \\
\hline Pesaran CD & $\begin{array}{l}8,3310 \\
(0,00) \\
\end{array}$ & $\begin{array}{l}11,5060 \\
(0,00)\end{array}$ & $\begin{array}{c}13,3800 \\
(0,00) \\
\end{array}$ & $\begin{array}{l}19,6480 \\
(0,00)\end{array}$ & $\begin{array}{l}9,2230 \\
(0,00)\end{array}$ \\
\hline
\end{tabular}


overlap with each other partially when compared with the results of the present study. However, unlike these results, Pae et al. (2005), Qiang (2007) and Sofian et al. (2011) reported negative relations between accounting conservatism and the market-to-book ratio (since ICP was calculated in this way).

When the estimation process is performed based on the Basu model (1997) in the financial institutions, it is understood from the cross-sectional and time $F$ values in Table 8 and the Hausman tests that when the dependent variable is EPS/SP the unit and time-effective fixed effects model is valid; when the dependent variable is $\mathrm{Q}$ the unit and time-effective random effects model is valid; when dependent variables are market-to-book ratio (MTB), VAIC and MVA the unit-effective random effects model is valid.

For companies that have positive Stock Market Return (SMR), when the Dummy Variable (DV) is taken as " 0 ", the effect of SMR on the dependent variable EPS/ SP $(0.4145-0=0.4145)$ is positive. When the DV is taken " 1 " for enterprises that have negative SMR, the effect of SMR on the dependent variable $(0.4145-0.3598=0.0547)$ is positive again. There is no asymmetry if the news is good and bad in the same way. It may be argued that the financial institutions have slight conservative accounting policies.

In case the dependent variable is selected as MTB and MVA it can be understood in Table 8 that the $S M R \times D V$ interaction component representing accounting conservatism has a positive effect on intellectual capital. But, in case the dependent variable is selected as VAIC that the SMR $\times D V$ interaction component representing accounting conservatism has a negative effect on intellectual capital. In this context, the $\mathrm{H}_{2}$ hypothesis will be accepted for these variables.

In case the basic econometric hypotheses are covered in panel data analysis, it may be argued that the results are accurate. These hypotheses are that the variance does not change according to units, the units are not autocorrelated among themselves, and that there is no inter-unit correlation. The test results of the hypotheses are shown in Table 7 and 8 . It was concluded for all models in Table 7 and 8 that the variance varied according to the units as a result of the Changed Wald Test. The Local Best Invariance Test, which was suggested by Durbin Watson and Baltagi-Wu, was carried out to determine whether or not there was autocorrelation. It is concluded that autocorrelation is important if these

Table 8: The analysis results of the Basu (1997) Model in the financial institutions

\begin{tabular}{|c|c|c|c|c|c|}
\hline Variables & EPS/SP & МTB(ICP) & VAIC & $\mathbf{Q}$ & MVA \\
\hline CONSTANT & $\begin{array}{c}-0,0347 \\
(0,0778)\end{array}$ & $\begin{array}{c}1,6318^{\mathrm{a}} \\
(0,3707)\end{array}$ & $\begin{array}{l}14,0292^{\mathrm{a}} \\
(4,4230)\end{array}$ & $\begin{array}{c}0,6911^{\mathrm{a}} \\
(0,1110)\end{array}$ & $\begin{array}{l}162,2841^{\mathrm{b}} \\
(80,0965)\end{array}$ \\
\hline DV & $\begin{array}{c}0,1024 \\
(0,1362) \\
\end{array}$ & $\begin{array}{l}-0,6625 \\
(0,4592) \\
\end{array}$ & $\begin{array}{c}6,2993 \\
(9,0283) \\
\end{array}$ & $\begin{array}{c}0,1216 \\
(0,2687)\end{array}$ & $\begin{array}{c}4,1326 \\
(48,0408) \\
\end{array}$ \\
\hline SMR & $\begin{array}{c}0,4145^{\mathrm{c}} \\
(0,2152)\end{array}$ & $\begin{array}{l}-0,2023 \\
(0,2479)\end{array}$ & $\begin{array}{c}9,9153 \\
(6,5162)\end{array}$ & $\begin{array}{l}-0,0187 \\
(0,1201)\end{array}$ & $\begin{array}{l}-27,6252 \\
(46,7722)\end{array}$ \\
\hline $\mathbf{S M R} \times \mathbf{D V}$ & $\begin{array}{l}-0,3598 \\
(0,2960)\end{array}$ & $\begin{array}{l}0,9534^{\mathrm{b}} \\
(0,4712)\end{array}$ & $\begin{array}{r}-12,7396^{\mathrm{a}} \\
(4,4986)\end{array}$ & $\begin{array}{c}1,2300 \\
(0,7606)\end{array}$ & $\begin{array}{c}343,4877^{c} \\
(199,0182)\end{array}$ \\
\hline $\mathbf{R}^{2}$ & 0,1408 & 0,0421 & 0,0297 & 0,0467 & 0,0207 \\
\hline $\mathbf{F}$ & 2,50 & $39,31^{\mathrm{a}}$ & $8,38^{\mathrm{b}}$ & $33,15^{\mathrm{a}}$ & $7,62^{c}$ \\
\hline $\begin{array}{l}\text { Cross- } \\
\text { Sectional F }\end{array}$ & $\begin{array}{c}3,08 \\
(0,00)\end{array}$ & $\begin{array}{l}21,72 \\
(0,00)\end{array}$ & $\begin{array}{l}44,96 \\
(0,00)\end{array}$ & $\begin{array}{l}36,86 \\
(0,00)\end{array}$ & $\begin{array}{l}57,15 \\
(0,00)\end{array}$ \\
\hline Time F & $\begin{array}{c}3,07 \\
(0,00)\end{array}$ & $\begin{array}{c}2.3 \mathrm{e}-13 \\
(1,00)\end{array}$ & $\begin{array}{c}0,28 \\
(0,30) \\
\end{array}$ & $\begin{array}{c}9,49 \\
(0,00) \\
\end{array}$ & $\begin{array}{c}0,00 \\
(1,00)\end{array}$ \\
\hline Hausman & $\begin{array}{l}77,90 \\
(0,00)\end{array}$ & $\begin{array}{c}0,59 \\
(0,90)\end{array}$ & $\begin{array}{c}0,28 \\
(0,96)\end{array}$ & $\begin{array}{c}1,19 \\
(0,75)\end{array}$ & $\begin{array}{c}0,82 \\
(0,84)\end{array}$ \\
\hline Wald Test & $\begin{array}{r}32802,41 \\
(0,00) \\
\end{array}$ & $\begin{array}{c}4,62 \\
(0,00) \\
\end{array}$ & $\begin{array}{c}4,62 \\
(0,00) \\
\end{array}$ & $\begin{array}{c}4,62 \\
(0,00) \\
\end{array}$ & $\begin{array}{c}4,62 \\
(0,00) \\
\end{array}$ \\
\hline $\begin{array}{l}\text { Bharvaga } \\
\text { Durbin } \\
\text { Watson }\end{array}$ & 1,3551 & 1,5822 & 1,1373 & 1,4261 & 0,5635 \\
\hline $\begin{array}{l}\text { Baltagi Wu } \\
\text { LBI }\end{array}$ & 1,4681 & 1,6340 & 1,3076 & 1,5055 & 0,9962 \\
\hline Pesaran CD & $\begin{array}{l}10,4070 \\
(0,00)\end{array}$ & $\begin{array}{l}9,2730 \\
(0,00)\end{array}$ & $\begin{array}{l}6,8800 \\
(0,00)\end{array}$ & $\begin{array}{l}14,8690 \\
(0,00)\end{array}$ & $\begin{array}{l}6,3790 \\
(0,00)\end{array}$ \\
\hline
\end{tabular}


test results are less than the critical value, i.e. "2". As it can be seen in Table 7 and 8, it is understood that the result value is less than 2 for all models. For the purpose of testing the presence of inter-unit correlation, the Pesaran Test was applied, it was determined as a result of this test that there was inter-unit correlation.

If the dependent variable is selected as EPS/SP to eliminate these econometric problems following the testing of the hypotheses, the "Driscoll Kraay" resistant estimator was employed, and if the dependent variable was selected as MTB(ICP), VAIC, Q and MVA, the "Arellano, Froot and Rogers" resistant estimators were employed. The errors that resulted according to the resistant estimators are shown in brackets in Table 7 and 8.

\section{The Effect of the Asymmetry of Accruals and Cash Flows Measurement Method on Intellectual Capital}

When the model estimation process is carried out according to Ball and Shivakumar (2005) model in the manufacturing industry, it is understood from the cross-sectional and time $F$ values and Hausman test results given in Table 8 that the unit-effective fixed effects model is valid if the dependent variable is Operating Accruals (ACC), if the dependent variable is MTB(ICP), VAIC and $Q$, the unit-effective random effects model is valid and if the dependent variable is MVA the unit and time-effective fixed effects model is valid.

When the analysis results are evaluated, the effect of CFO on dependent variable ACC is negative $(-1,1184+0=-1,1184)$ when the Dummy Variable (DV) is taken as " 0 " for the companies that have positive CFO values. However, if the Dummy Variable (DV) is taken as "1" for companies that have negative CFO values, the effect of CFO on the dependent variable is positive $(-1,1184+1,7479=0,6295)$. In other words, there is an asymmetry if the news is good and bad. It is seen that the interaction coefficient component (CFOXDV) which is accepted as an indicator of accounting conservatism is 1,7479 according to the accruals and asymmetry of cash flows measurement method. According to this result, it is possible to argue that companies have conservative accounting policies. It is also understood in Table 8 that if the cash flows obtained from operating activities (CFO) are increased by one unit, the activity

Table 9: The analysis results of the Ball and Shivakumar (2005) Model in the manufacturing industry

\begin{tabular}{|c|c|c|c|c|c|}
\hline Variables & $\mathrm{ACC}$ & MTB(ICP) & VAIC & $\mathbf{Q}$ & MVA \\
\hline CONSTANT & $\begin{array}{l}-34,0361 \\
(24,5451) \\
\end{array}$ & $\begin{array}{c}4,9623 \\
(3,0174)\end{array}$ & $\begin{array}{l}26,7227^{a} \\
(7,0696)\end{array}$ & $\begin{array}{c}23,4930 \\
(15,3559)\end{array}$ & $\begin{array}{l}213,1397^{\mathrm{a}} \\
(55,8540)\end{array}$ \\
\hline DV & $\begin{array}{l}-11,2082 \\
(23,9032) \\
\end{array}$ & $\begin{array}{c}0,7322 \\
(1,7289) \\
\end{array}$ & $\begin{array}{l}-3,5316 \\
(5,6434)\end{array}$ & $\begin{array}{l}-8,7662 \\
(6,9355) \\
\end{array}$ & $\begin{array}{l}-51,9255 \\
(29,9685) \\
\end{array}$ \\
\hline CFO & $\begin{array}{l}-1,1184^{a} \\
(0,3666) \\
\end{array}$ & $\begin{array}{c}0,0012 \\
(0,0009)\end{array}$ & $\begin{array}{c}0,0012 \\
(0,0164)\end{array}$ & $\begin{array}{c}0,0220 \\
(0,0276)\end{array}$ & $\begin{array}{c}0,1541 \\
(0,3547) \\
\end{array}$ \\
\hline CFO $\times \mathrm{DV}$ & $\begin{array}{l}1,7479^{a} \\
(0,5121)\end{array}$ & $\begin{array}{c}0,0009 \\
(0,0039)\end{array}$ & $\begin{array}{c}0,0077 \\
(0,0258)\end{array}$ & $\begin{array}{l}-0,0562 \\
(0,0611)\end{array}$ & $\begin{array}{l}-1,1760 \\
(1,3758)\end{array}$ \\
\hline $\mathbf{R}^{2}$ & 0,1640 & 0,0021 & 0,0006 & 0,0074 & 0,0138 \\
\hline $\mathbf{F}$ & $6,43^{a}$ & 2,33 & 3,69 & 1,84 & 2,36 \\
\hline $\begin{array}{l}\text { Cross- } \\
\text { Sectional F }\end{array}$ & $\begin{array}{l}73,06 \\
(0,00) \\
\end{array}$ & $\begin{array}{c}858,75 \\
(0,00)\end{array}$ & $\begin{array}{l}115,63 \\
(0,00)\end{array}$ & $\begin{array}{r}529,55 \\
(0,00) \\
\end{array}$ & $\begin{array}{l}10,52 \\
(0,00) \\
\end{array}$ \\
\hline Time F & $\begin{array}{c}0,33 \\
(0,98) \\
\end{array}$ & $\begin{array}{c}0,00 \\
(1,00)\end{array}$ & $\begin{array}{c}1,53 \\
(0,11) \\
\end{array}$ & $\begin{array}{c}0,00 \\
(1,00)\end{array}$ & $\begin{array}{c}2,44 \\
(0,00) \\
\end{array}$ \\
\hline Hausman & $\begin{array}{r}188,21 \\
(0,00)\end{array}$ & $\begin{array}{c}0,24 \\
(0,97)\end{array}$ & $\begin{array}{c}0,75 \\
(0,86) \\
\end{array}$ & $\begin{array}{c}0,17 \\
(0,98)\end{array}$ & $\begin{array}{l}38,36 \\
(0,00)\end{array}$ \\
\hline Wald Test & $\begin{array}{c}1.1 \mathrm{e}+09 \\
(0,00)\end{array}$ & $\begin{array}{l}15,08 \\
(0,00)\end{array}$ & $\begin{array}{l}15,07 \\
(0,00)\end{array}$ & $\begin{array}{l}15,08 \\
(0,00)\end{array}$ & $\begin{array}{c}9.3 \mathrm{e}+06 \\
(0,00)\end{array}$ \\
\hline $\begin{array}{l}\text { Bharvaga } \\
\text { Durbin } \\
\text { Watson }\end{array}$ & 0,9020 & 1,4783 & 1,3074 & 0,7262 & 0,5517 \\
\hline $\begin{array}{l}\text { Baltagi Wu } \\
\text { LBI }\end{array}$ & 1,2699 & 1,7369 & 1,4413 & 0,8776 & 0,9690 \\
\hline Pesaran CD & $\begin{array}{r}-1,1090 \\
(0,27)\end{array}$ & $\begin{array}{c}15,0780 \\
(0,00)\end{array}$ & $\begin{array}{l}6,0840 \\
(0,00)\end{array}$ & $\begin{array}{l}0,9500 \\
(0,00)\end{array}$ & $\begin{array}{c}14,9350 \\
(0,00)\end{array}$ \\
\hline
\end{tabular}


accruals (ACC) will decrease by 1,1184 units. However, it is understood in Table 9 that the interaction component (CFOXDV), which is the indicator of accounting conservatism according to this measurement method, does not have a significant effect on the dependent variables (MTB or ICP, VAIC, Q, MVA) that express the intellectual capital. As a result of these findings, the $\mathrm{H}_{3}$ hypothesis will be rejected for all the dependent variables that express the intellectual capital. In the literature review, no studies were found that had consistent results with the present study. However, unlike the results that were found, Pae et al. (2005), Qiang (2007) and Sofian et al. (2011) reported negative relationship between accounting conservatism and the ratio of market value to book value; and Chen et al. (2005) and Akmeşe (2006), Sana'a NM (2016) reported positive relationship.

When the model estimation process is carried out according to Ball and Shivakumar (2005) model in the financial institutions, it is understood from the cross-sectional and time $F$ values and Hausman test results given in Table 10 that the unit-effective fixed effects model is valid, if the dependent variable is MVA, if the dependent variable is $\mathrm{Q}$ the unit and time-effective random effects model is valid and if the dependent vari- able is ACC, MTB(ICP) and VAIC the unit-effective random effects model is valid.

The effect of CFO on dependent variable ACC is positive $(0,2708+0=0,2708)$ when the Dummy Variable $(D V)$ is taken as " 0 "for the companies that have positive CFO values. But, if the Dummy Variable (DV) is taken as "1" for companies that have negative CFO values, the effect of CFO on the dependent variable is negative $(0,2708-0,4537=-0,1829)$. So, there is an asymmetry if the news is good and bad. According to this result, it is possible to argue that companies have conservative accounting policies. Unlike the manufacturing industry, in Table 9 that the interaction component (CFOXDV), which is the indicator of accounting conservatism according to this measurement method, does have a positive effect on two dependent variables (MTB and VAIC). As a result of these findings, the $\mathrm{H}_{4}$ hypothesis will be accepted for these dependent variables that express the intellectual capital.

When the explanations that were made for the basic econometric assumptions in Basu (1997) Model are considered, it is understood in Table 9 and 10 that there is a heteroscedasticity, autocorrelation, and inter-unit correlation problems for all dependent variables in this model. For the purpose of eliminating the econometric

Table 10: The analysis results of the Ball and Shivakumar (2005) Model in the financial institutions

\begin{tabular}{|c|c|c|c|c|c|}
\hline Variables & $\mathrm{ACC}$ & МTB(ICP) & VAIC & $\mathbf{Q}$ & MVA \\
\hline CONSTANT & $\begin{array}{c}5,3104 \\
(56,4087) \\
\end{array}$ & $\begin{array}{l}1,3790^{\mathrm{a}} \\
(0,2083)\end{array}$ & $\begin{array}{l}22,0848^{\mathrm{a}} \\
(4,1368)\end{array}$ & $\begin{array}{r}0,5911^{\mathrm{a}} \\
(0,0806)\end{array}$ & $\begin{array}{l}132,1117^{\mathrm{a}} \\
(32,0505)\end{array}$ \\
\hline DV & $\begin{array}{c}42,707 \\
(41,5264)\end{array}$ & $\begin{array}{c}-0,3230 \\
(0,2589)\end{array}$ & $\begin{array}{l}-8,2591^{\mathrm{b}} \\
(4,0698)\end{array}$ & $\begin{array}{c}0,0466 \\
(0,1531)\end{array}$ & $\begin{array}{l}101,9007^{b} \\
(32,4765)\end{array}$ \\
\hline CFO & $\begin{array}{c}0,2708 \\
(0,2696)\end{array}$ & $\begin{array}{l}-0,0006^{\mathrm{c}} \\
(0,0003)\end{array}$ & $\begin{array}{l}-0,0107^{b} \\
(0,0044)\end{array}$ & $\begin{array}{l}-0,0008 \\
(0,0009)\end{array}$ & $\begin{array}{c}0,0121 \\
(0,2201)\end{array}$ \\
\hline CFO $\times$ DV & $\begin{array}{c}-0,4537 \\
(0,5569)\end{array}$ & $\begin{array}{c}0,0009^{c} \\
(0,0005)\end{array}$ & $\begin{array}{r}0,0125^{\mathrm{b}} \\
(0,0055)\end{array}$ & $\begin{array}{c}0,0001 \\
(0,0001)\end{array}$ & $\begin{array}{c}0,0723 \\
(0,4326)\end{array}$ \\
\hline $\mathbf{R}^{2}$ & 0,0247 & 0,0060 & 0,0122 & 0,0002 & 0,0150 \\
\hline $\mathbf{F}$ & 21,07 & 5,12 & $14,87^{\mathrm{a}}$ & 3,92 & $5,94^{\mathrm{b}}$ \\
\hline $\begin{array}{l}\text { Cross- } \\
\text { Sectional F } \\
\end{array}$ & $\begin{array}{r}298,56 \\
(0,00) \\
\end{array}$ & $\begin{array}{l}23,45 \\
(0,00) \\
\end{array}$ & $\begin{array}{l}48,03 \\
(0,00) \\
\end{array}$ & $\begin{array}{l}43,19 \\
(0,00) \\
\end{array}$ & $\begin{array}{c}8,90 \\
(0,00) \\
\end{array}$ \\
\hline Time F & $\begin{array}{c}0,00 \\
(1,00)\end{array}$ & $\begin{array}{c}0,30 \\
(0,29)\end{array}$ & $\begin{array}{c}0,91 \\
(0,17)\end{array}$ & $\begin{array}{l}15,77 \\
(0,00)\end{array}$ & $\begin{array}{c}1,16 \\
(0,32)\end{array}$ \\
\hline Hausman & $\begin{array}{c}1,89 \\
(0,60)\end{array}$ & $\begin{array}{c}2,21 \\
(0,53)\end{array}$ & $\begin{array}{c}2,68 \\
(0,44)\end{array}$ & $\begin{array}{c}1,77 \\
(0,62)\end{array}$ & $\begin{array}{l}72,59 \\
(0,00)\end{array}$ \\
\hline Wald Test & $\begin{array}{l}21,58 \\
(0,00)\end{array}$ & $\begin{array}{l}21,57 \\
(0,00)\end{array}$ & $\begin{array}{l}21,58 \\
(0,00)\end{array}$ & $\begin{array}{l}21,58 \\
(0,00)\end{array}$ & $\begin{array}{c}1.4 \mathrm{e}+06 \\
(0,00)\end{array}$ \\
\hline $\begin{array}{l}\text { Bharvaga } \\
\text { Durbin } \\
\text { Watson }\end{array}$ & 1,1682 & 1,5683 & 1,1476 & 1,4044 & 0,6739 \\
\hline $\begin{array}{l}\text { Baltagi Wu } \\
\text { LBI }\end{array}$ & 1,2478 & 1,6291 & 1,3215 & 1,4830 & 1,0945 \\
\hline Pesaran CD & $\begin{array}{l}1,9800 \\
(0,05)\end{array}$ & $\begin{array}{l}15,0320 \\
(0,00)\end{array}$ & $\begin{array}{c}4,1330 \\
(0,00)\end{array}$ & $\begin{array}{c}23,1530 \\
(0,00)\end{array}$ & $\begin{array}{c}9,7330 \\
(0,00)\end{array}$ \\
\hline
\end{tabular}


problems mentioned above, appropriate resistant estimators were used, the resistant standard errors that were obtained according to the analysis results made with resistant estimators are given in brackets in Table 9 and 10.

\section{The Effect of the Market-to-Book Ratio Measurement Method on Intellectual Capital}

It was considered useful that an issue was clarified before the evaluation of the estimation process of Beaver and Ryan (2000) Model and the analysis results. In this model, the market-to-book ratio variable, which is the dependent variable in the panel data regression equation that was employed in the measurement of accounting conservatism, was also the formula used in the calculation of intellectual capital performance or market-to-book ratio in this study. For this reason, the analysis results of this model overlap with both dependent variables in a one-to-one fashion. For this reason, no need was felt to provide the results for the intellectual capital performance (ICP) dependent variable.

In the Beaver and Ryan (2000) Model, the inclination component (bias) $a_{i}$, which is the indicator of accounting conservatism, was calculated for the companies of manufacturing industry and financial institutions that were included in the analysis separately. In addition, this calculation was repeated for each dependent variable in both sectors. However, instead of creating tables for the inclination components $\left(a_{i}\right)$ of the companies, it was considered to be more proper to draw graphics for the study. These graphics are given in the appendix. When the MVA dependent variable which express the intellectual capital are selected, it can be seen in the graphics that there are companies of manufacturing industry and financial institutions that had high inclination component that expresses the accounting conservatism $\left(a_{i}\right)$.

Table 11: The analysis results of the Beaver and Ryan (2005) Model in the manufacturing industry

\begin{tabular}{|c|c|c|c|c|}
\hline & МТВ & VAIC & $\mathbf{Q}$ & MVA \\
\hline CONSTANT & $\begin{array}{l}11,9232^{a} \\
(0,6498)\end{array}$ & $\begin{array}{l}19,7120^{\mathrm{a}} \\
(2,2502)\end{array}$ & $\begin{array}{l}27,8934^{\mathrm{a}} \\
(4,0011)\end{array}$ & $\begin{array}{l}391,8977^{\mathrm{a}} \\
(47,7989)\end{array}$ \\
\hline ROE & $\begin{array}{l}-9,3343^{\mathrm{a}} \\
(0,8131) \\
\end{array}$ & $\begin{array}{l}-2,6787 \\
(2,7045)\end{array}$ & $\begin{array}{l}-0,1499 \\
(4,8558)\end{array}$ & $\begin{array}{c}-14,0912 \\
(63,4987) \\
\end{array}$ \\
\hline ROE (-1) & $\begin{array}{l}-5,7492^{a} \\
(1,0220)\end{array}$ & $\begin{array}{l}-3,2276 \\
(3,3108)\end{array}$ & $\begin{array}{c}2,8415 \\
(5,9854)\end{array}$ & $\begin{array}{c}25,9428 \\
(81,8682) \\
\end{array}$ \\
\hline ROE (-2) & $\begin{array}{l}-8,0790^{a} \\
(1,2451)\end{array}$ & $\begin{array}{l}-0,7528 \\
(3,9266)\end{array}$ & $\begin{array}{l}-0,8603 \\
(7,1401)\end{array}$ & $\begin{array}{c}-36,9646 \\
(104,1406)\end{array}$ \\
\hline ROE (-3) & $\begin{array}{l}-7,3539^{a} \\
(1,3527)\end{array}$ & $\begin{array}{l}-2,8267 \\
(4,1123) \\
\end{array}$ & $\begin{array}{c}2,0541 \\
(7,5528) \\
\end{array}$ & $\begin{array}{c}-7,6104 \\
(117,2245) \\
\end{array}$ \\
\hline ROE (-4) & $\begin{array}{l}-8,9316^{a} \\
(1,3552)\end{array}$ & $\begin{array}{l}-1,3719 \\
(4,0431)\end{array}$ & $\begin{array}{l}-0,1292 \\
(7,4525) \\
\end{array}$ & $\begin{array}{c}-36,2846 \\
(121,8865) \\
\end{array}$ \\
\hline ROE (-5) & $\begin{array}{l}-0,0886 \\
(1,8797) \\
\end{array}$ & $\begin{array}{l}-6,6499 \\
(6,5591) \\
\end{array}$ & $\begin{array}{c}6,5638 \\
(11,6336) \\
\end{array}$ & $\begin{array}{c}77,6294 \\
(139,6450) \\
\end{array}$ \\
\hline ROE (-6) & $\begin{array}{c}0,0145 \\
(1,8101) \\
\end{array}$ & $\begin{array}{l}-1,1140 \\
(6,2413) \\
\end{array}$ & $\begin{array}{c}-2,7420 \\
(11,1204) \\
\end{array}$ & $\begin{array}{c}-35,3448 \\
(133,3186) \\
\end{array}$ \\
\hline $\mathbf{R}^{2}$ & 0,5231 & 0,0231 & 0,0037 & 0,0055 \\
\hline $\mathbf{F}$ & $21,46^{\mathrm{a}}$ & 0,46 & 0,07 & 0,11 \\
\hline $\begin{array}{l}\text { Cross-Sectional } \\
\text { F }\end{array}$ & $\begin{array}{l}84,53 \\
(0,00) \\
\end{array}$ & $\begin{array}{l}22,76 \\
(0,00) \\
\end{array}$ & $\begin{array}{c}183,13 \\
(0,00) \\
\end{array}$ & $\begin{array}{l}23,27 \\
(0,00) \\
\end{array}$ \\
\hline Time F & $\begin{array}{c}0,88 \\
(0,56) \\
\end{array}$ & $\begin{array}{c}1,38 \\
(0,18) \\
\end{array}$ & $\begin{array}{c}0,29 \\
(0,99) \\
\end{array}$ & $\begin{array}{c}1,75 \\
(0,06) \\
\end{array}$ \\
\hline Hausman & & ain study $\mathrm{u}$ & as the basis & \\
\hline Wald Test & $\begin{array}{c}0,00 \\
(1,00)\end{array}$ & $\begin{array}{c}0,00 \\
(1,00)\end{array}$ & $\begin{array}{c}0,00 \\
(1,00)\end{array}$ & $\begin{array}{c}0,00 \\
(1,00) \\
\end{array}$ \\
\hline $\begin{array}{l}\text { Bhargava } \\
\text { Durbin Watson }\end{array}$ & 1,2875 & 1,4363 & 1,3660 & 0,9990 \\
\hline Baltagi Wu LBI & 1,2875 & 1,4363 & 1,3660 & 0,9990 \\
\hline Pesaran CD & $\begin{array}{c}-0,4930 \\
(0,62)\end{array}$ & $\begin{array}{c}0,3950 \\
(0,69)\end{array}$ & $\begin{array}{c}0,8960 \\
(0,37)\end{array}$ & $\begin{array}{c}9,8960 \\
(0,00)\end{array}$ \\
\hline
\end{tabular}


According to Beaver and Ryan (2000) Model, it is seen in Table 11 and 12 that there is a unit effect for all dependent variables; however, there is no time effect. However, since it was understood that the direct constant effects model was taken as the basis in the study conducted by Beaver and Ryan (2000) without giving the Hausman Test results, the methodology of the authors was followed and it was accepted that the unit effect constant effects model was valid for all dependent variables.

When the results of the analysis are evaluated, it is seen in all models that the constant terms are significant at 0.01 level. In addition, it is seen in Table 10 that in case the dependent variable is selected as market-to-book raito, the Return on Equity (ROE) and the delay components of Return on Equity (ROE) have a significant effect on MTB. However, in case the Approximately Tobin Q (Q) ratio, VAIC and the Market Value Added (MVA) are selected as dependent variables, it is seen that the
Return on Equity (ROE) and delay components do not have a significant effect on these dependent variables.

When the results of the analysis are evaluated, it is seen in all models that the constant terms are significant at 0.01 level. However, in Table 12, it is seen that any dependent variable has no significant effect on the delay components of Return on Equity (ROE) and Return on Equity (ROE).

According to these results, the MVA is selected as the dependent variable, it is understood that the enterprises that have high inclination component $\left(a_{i}\right)$, which express the accounting conservatism, in the attached graphic (appendix) are active in the manufacturing industry and financial institutions. In this case, the $\mathrm{H}_{5}$ and $\mathrm{H}_{6}$ hypothesis are accepted for the MVA dependent variable.

When the test results of the basic econometric hypotheses are examined, it is understood from the

Table 12: The analysis results of the Beaver and Ryan (2005) Model in the financial institutions

\begin{tabular}{|c|c|c|c|c|}
\hline & MTB & VAIC & $\mathbf{Q}$ & MVA \\
\hline CONSTANT & $\begin{array}{l}1,6996^{\mathrm{a}} \\
(0,0690) \\
\end{array}$ & $\begin{array}{l}14,4469^{\mathrm{a}} \\
(1,3758) \\
\end{array}$ & $\begin{array}{l}0,6619^{\mathrm{a}} \\
(0,0739) \\
\end{array}$ & $\begin{array}{l}136,0576^{a} \\
(19,4092) \\
\end{array}$ \\
\hline ROE & $\begin{array}{l}-0,4091^{\mathrm{b}} \\
(0,1869) \\
\end{array}$ & $\begin{array}{l}-1,0116 \\
(4,0541)\end{array}$ & $\begin{array}{c}0,0155 \\
(0,0311) \\
\end{array}$ & $\begin{array}{c}5,1695 \\
(55,3091)\end{array}$ \\
\hline ROE (-1) & $\begin{array}{l}-0,0988 \\
(0,2523)\end{array}$ & $\begin{array}{l}-0,1749 \\
(6,0271)\end{array}$ & $\begin{array}{l}-0,5282^{\mathrm{a}} \\
(0,0314)\end{array}$ & $\begin{array}{l}-81,2048 \\
(92,5712)\end{array}$ \\
\hline ROE (-2) & $\begin{array}{l}-0,2597 \\
(0,2729) \\
\end{array}$ & $\begin{array}{l}-0,3311 \\
(6,9617) \\
\end{array}$ & $\begin{array}{l}-0,0696^{\mathrm{b}} \\
(0,0298) \\
\end{array}$ & $\begin{array}{c}-10,7378 \\
(118,0070)\end{array}$ \\
\hline ROE (-3) & $\begin{array}{l}-0,1062 \\
(0,2801) \\
\end{array}$ & $\begin{array}{l}-0,4070 \\
(7,4274)\end{array}$ & $\begin{array}{c}0,0130 \\
(0,0326)\end{array}$ & $\begin{array}{c}-5,2709 \\
(135,7585)\end{array}$ \\
\hline ROE (-4) & $\begin{array}{c}-0,1424 \\
(0,2842)\end{array}$ & $\begin{array}{c}-0,3575 \\
(7,7097) \\
\end{array}$ & $\begin{array}{l}-0,0463 \\
(0,0385) \\
\end{array}$ & $\begin{array}{c}-12,9989 \\
(149,1991) \\
\end{array}$ \\
\hline ROE (-5) & $\begin{array}{l}-0,3436 \\
(0,2832)\end{array}$ & $\begin{array}{l}-2,1689 \\
(7,2184)\end{array}$ & $\begin{array}{l}0,7621^{\mathrm{b}} \\
(0,3524)\end{array}$ & $\begin{array}{c}-34,5988 \\
(137,3217)\end{array}$ \\
\hline ROE (-6) & $\begin{array}{l}-0,5826 \\
(0,4291)\end{array}$ & $\begin{array}{l}-4,8410 \\
(9,3433)\end{array}$ & $\begin{array}{c}0,7376^{c} \\
(0,3975)\end{array}$ & $\begin{array}{c}-54,8427 \\
(136,1874)\end{array}$ \\
\hline $\mathbf{R}^{2}$ & 0,6147 & 0,0230 & 0,5985 & 0,4624 \\
\hline $\mathbf{F}$ & $22,11^{\mathrm{a}}$ & 0,33 & $596,16^{\mathrm{a}}$ & $11,92^{\mathrm{a}}$ \\
\hline $\begin{array}{l}\text { Cross-Sectional } \\
\text { F }\end{array}$ & $\begin{array}{l}22,79 \\
(0,00) \\
\end{array}$ & $\begin{array}{c}6,22 \\
(0,00) \\
\end{array}$ & $\begin{array}{l}19,02 \\
(0,00) \\
\end{array}$ & $\begin{array}{c}9,31 \\
(0,00)\end{array}$ \\
\hline Time F & $\begin{array}{c}3,40 \\
(0,00) \\
\end{array}$ & $\begin{array}{c}1,50 \\
(0,13) \\
\end{array}$ & $\begin{array}{c}3,17 \\
(0,00) \\
\end{array}$ & $\begin{array}{c}0,82 \\
(0,62) \\
\end{array}$ \\
\hline Hausman & & nain study $v$ & as the basis & \\
\hline Wald Test & $\begin{array}{c}0,00 \\
(1,00)\end{array}$ & $\begin{array}{c}0,00 \\
(1,00)\end{array}$ & $\begin{array}{c}0,00 \\
(1,00) \\
\end{array}$ & $\begin{array}{c}0,00 \\
(1,00)\end{array}$ \\
\hline $\begin{array}{l}\text { Bhargava } \\
\text { Durbin Watson }\end{array}$ & 1,2666 & 0,9579 & 1,8307 & 0,5685 \\
\hline Baltagi Wu LBI & 1,6141 & 1,3757 & 2,1185 & 1,3333 \\
\hline Pesaran CD & $\begin{array}{l}1,6210 \\
(0,11)\end{array}$ & $\begin{array}{l}3,6800 \\
(0,00)\end{array}$ & $\begin{array}{l}2,9420 \\
(0,00)\end{array}$ & $\begin{array}{l}0,9620 \\
(0,34)\end{array}$ \\
\hline
\end{tabular}


test results given in Table 11 and 12 that there is only autocorrelation problem for all the involved models. The standard errors are given in brackets in Table 11 and 12 by using the proper resistance estimator.

When compared with the studies in the literature, the results reported by Chen et al. (2005), Akmese (2006), Sana'a NM (2016) and Bayraktoroglu, at al. (2019) partly overlap with this study. However, Pae et al. (2005), Qiang (2007) and Sofian et al. (2011) reported a negative relationship between accounting conservatism and the ratio of the market value to the book value. Cheng (2005), on the other hand, reported that the Return on Equity of the companies applying conservative accounting policies was high, which is partly related to the study. However, when the results given in Table 11 and 12 are analysed, it is seen that the Return on Equity and its delay component coefficients are negative.

\section{The Effect of Negative Accruals Measurement Method on Intellectual Capital}

Before evaluating the Givoly and Hayn (2000) Model and the Analysis Results, a figure was created to see how negative accruals (non-activity accruals) as indicators of accounting conservatism followed a course through the observed years. The trend of negative accruals during the observation period is given in Figure 1 .

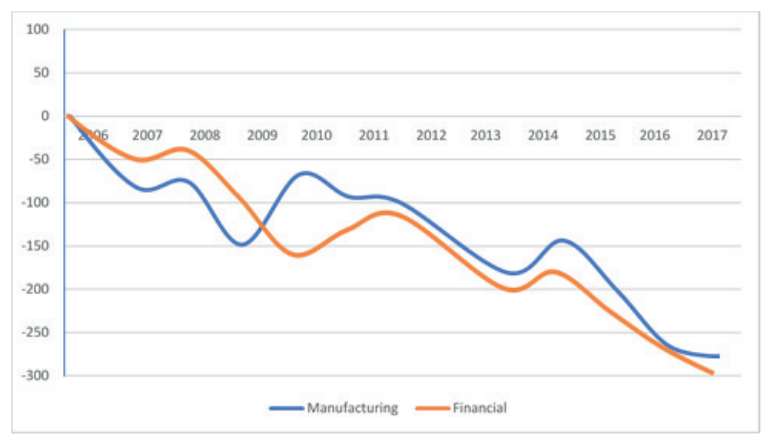

Figure 1: The trend of negative accruals of the companies of manufacturing industry and financial institutions in BIST 100 Index in Turkey

When Figure 1 was created, the companies of manufacturing industry and financial institutions that were included in the scope of the analyses were taken as a single company, and the above-mentioned accruals of these enterprises were evaluated as a whole. When the figure is examined, it is seen that non-operating accruals had a negative progression between 2006 and 2017 in both sectors, which is the observation period in the present study, except for small increases in several years, and were always negative. It is possible to argue that the bigger the accruals, the greater the accounting conservatism levels. As it can be seen in Figure 1, it is possible to argue that the accounting conservatism level of these companies that were included in the analysis in the BIST 100 Index is very large.

Table 13: The analysis results on Givoly and Hayn (2000) Model in the manufacturing industry

\begin{tabular}{|c|c|c|c|c|}
\hline & MTB(ICP) & VAIC & $\mathbf{Q}$ & MVA \\
\hline CONSTANT & $\begin{array}{l}5,8743^{\mathrm{a}} \\
(0,3276)\end{array}$ & $\begin{array}{l}26,4555^{\mathrm{a}} \\
(7,7446)\end{array}$ & $\begin{array}{c}22,9584 \\
(15,1941)\end{array}$ & $\begin{array}{l}221,2848^{\mathrm{a}} \\
(63,8663)\end{array}$ \\
\hline NA & $\begin{array}{l}0,0590^{a} \\
(0,0092)\end{array}$ & $\begin{array}{l}0,0442^{\mathrm{a}} \\
(0,0163)\end{array}$ & $\begin{array}{l}-0,0049 \\
(0,0219)\end{array}$ & $\begin{array}{c}0,2269 \\
(1,0207)\end{array}$ \\
\hline $\mathbf{R}^{2}$ & 0,0559 & 0,0001 & 0,0001 & 0,0003 \\
\hline $\mathbf{F}$ & $41,52^{\mathrm{a}}$ & $7,37^{\mathrm{a}}$ & 0,05 & $0,05^{\mathrm{a}}$ \\
\hline $\begin{array}{l}\text { Cross-Sectional } \\
\text { F }\end{array}$ & $\begin{array}{l}109,66 \\
(0,00)\end{array}$ & $\begin{array}{l}114,85 \\
(0,00)\end{array}$ & $\begin{array}{r}528,03 \\
(0,00)\end{array}$ & $\begin{array}{l}13,06 \\
(0,00)\end{array}$ \\
\hline Time F & $\begin{array}{c}0,38 \\
(0,96)\end{array}$ & $\begin{array}{c}1,57 \\
(0,11)\end{array}$ & $\begin{array}{c}0,00 \\
(1,00)\end{array}$ & $\begin{array}{c}2,16 \\
(0,01)\end{array}$ \\
\hline Hausman & $\begin{array}{l}19,01 \\
(0,00)\end{array}$ & $\begin{array}{c}0,58 \\
(0,45)\end{array}$ & $\begin{array}{c}0,08 \\
(0,78)\end{array}$ & $\begin{array}{l}21,83 \\
(0,00)\end{array}$ \\
\hline Wald Test & $\begin{array}{c}1.1 \mathrm{e}+09 \\
(0,00)\end{array}$ & $\begin{array}{l}12,94 \\
(0,00)\end{array}$ & $\begin{array}{l}12,93 \\
(0,00)\end{array}$ & $\begin{array}{c}5.0 \mathrm{e}+09 \\
(0,00)\end{array}$ \\
\hline $\begin{array}{l}\text { Bhargava } \\
\text { Durbin Watson }\end{array}$ & 1,5012 & 1,3069 & 0,7214 & 0,5103 \\
\hline Baltagi Wu LBI & 1,7670 & 1,4411 & 0,8762 & 0,9437 \\
\hline Pesaran CD & $\begin{array}{c}19,0410 \\
(0,00)\end{array}$ & $\begin{array}{l}6,9420 \\
(0,00)\end{array}$ & $\begin{array}{l}16,2810 \\
(0,00)\end{array}$ & $\begin{array}{c}25,8140 \\
(0,00)\end{array}$ \\
\hline
\end{tabular}


It is seen based on the results given in Table 13 (cross-sectional and time F, Hausman) that according to the estimation process for the Givoly and Hayn (2000) Model in the manufacturing industry, when the dependent variables are selected MTB, the unit-effective fixed effects model is valid; if the MVA selected, the unit and time-effective fixed effects model is valid and if the VAIC and Q selected, the unit-effective random effects model is valid.

When the results of the analysis are considered, it is possible to argue that a one-unit increase in the negative accrual (NA) amount will increase the Intellectual Capital Performance (ICP) at a rate of 0.0590 units, the Value-Added Intellectual Coefficient (VAIC) at a rate of 0.0442 units. In addition, it is seen in Table 12 that -except for Approximately Tobin Q (Q)- the constant terms are statistically significant. According to these results, it is seen that accounting conservatism that was measured according to Negative Accruals Measurement Method had positive effects on intellectual capital. For this reason, the $\mathrm{H}_{7}$ hypothesis is accepted for the above-mentioned dependent variables.

It is seen based on the results given in Table 14 (cross-sectional and time F, Hausman) that according to the estimation process for the Givoly and Hayn (2000) Model in the financial institutions, when the dependent variables are selected MTB and VAIC, the unit-effective random effects model is valid; if the $\mathrm{Q}$ selected the unit and time-effective random effects model is valid and if the MVA selected the unit-effective fixed effects model is valid.

When the results of the analysis are considered, it is possible to argue that a one-unit increase in the negative accrual (NA) amount will increase the VAIC at a rate of 0.0278 units, the $Q$ at a rate of 0.0012 units. It is seen in Table 13 that the constant terms are statistically significant. According to these results, it is seen that accounting conservatism that was measured according to Negative Accruals Measurement Method had positive effects on intellectual capital. For this reason, the $\mathrm{H}_{8}$ hypothesis is accepted for the above-mentioned dependent variables.

When the test results of the hypotheses are exami$n e d$, it is seen that there is a heteroscedasticity problem as a result of the Changed Wald Test. When the results of the Durbin Watson and Baltagi-Wu tests are examined, it is seen that the results are lower than 2, which is the critical value. In this situation, it is understood that there is autocorrelation problem. According to the Pesaran Test results, on the other hand, it is understood in Table 13 and 14 that there is a correlation problem between the units. For the purpose of solving these problems, proper resistant estimator was used; and the resistant standard errors that were obtained as a result of this estimations are given in brackets in Table 13 and 14.

Like these results, Francis et al. (2013) and Sana'a NM (2016) determined that accounting conservatism had

Table 14: The analysis results on Givoly and Hayn (2000) Model in the financial Institutions

\begin{tabular}{|c|c|c|c|c|}
\hline & MTB(ICP) & VAIC & $\mathbf{Q}$ & MVA \\
\hline CONSTANT & $\begin{array}{l}1,2752^{\mathrm{a}} \\
(0,1887)\end{array}$ & $\begin{array}{l}19,6443^{\mathrm{a}} \\
(3,6001)\end{array}$ & $\begin{array}{l}0,6081^{\mathrm{a}} \\
(0,0896)\end{array}$ & $\begin{array}{l}157,2078^{\mathrm{a}} \\
(40,6636)\end{array}$ \\
\hline NA & $\begin{array}{c}0,0019 \\
(0,0012)\end{array}$ & $\begin{array}{l}0,0278^{c} \\
(0,0147)\end{array}$ & $\begin{array}{l}0,0012^{\mathrm{a}} \\
(0,0003)\end{array}$ & $\begin{array}{c}0,0167 \\
(1,1101)\end{array}$ \\
\hline $\mathbf{R}^{2}$ & 0,0031 & 0,0001 & 0,0002 & 0,0001 \\
\hline $\mathbf{F}$ & 2,60 & $3,56^{\mathrm{c}}$ & $10,13^{\mathrm{a}}$ & 0,00 \\
\hline $\begin{array}{l}\text { Cross-Sectional } \\
\text { F }\end{array}$ & $\begin{array}{l}25,18 \\
(0,00)\end{array}$ & $\begin{array}{l}49,96 \\
(0,00) \\
\end{array}$ & $\begin{array}{l}40,94 \\
(0,00) \\
\end{array}$ & $\begin{array}{c}6,34 \\
(0,00) \\
\end{array}$ \\
\hline Time F & $\begin{array}{c}0,31 \\
(0,29)\end{array}$ & $\begin{array}{c}1,03 \\
(0,15)\end{array}$ & $\begin{array}{l}16,80 \\
(0,00)\end{array}$ & $\begin{array}{c}1,38 \\
(0,18)\end{array}$ \\
\hline Hausman & $\begin{array}{c}0,38 \\
(0,54)\end{array}$ & $\begin{array}{c}0,74 \\
(0,39)\end{array}$ & $\begin{array}{c}1,59 \\
(0,21)\end{array}$ & $\begin{array}{l}24,01 \\
(0,00)\end{array}$ \\
\hline Wald Test & $\begin{array}{c}5,02 \\
(0,00)\end{array}$ & $\begin{array}{c}5,01 \\
(0,00)\end{array}$ & $\begin{array}{c}5,02 \\
(0,00)\end{array}$ & $\begin{array}{c}1.4 \mathrm{e}+07 \\
(0,00)\end{array}$ \\
\hline $\begin{array}{l}\text { Bhargava } \\
\text { Durbin Watson }\end{array}$ & 1,5621 & 1,1349 & 1,4014 & 0,6728 \\
\hline Baltagi Wu LBI & 1,6229 & 1,3122 & 1,4800 & 1,0967 \\
\hline Pesaran CD & $\begin{array}{c}16,2990 \\
(0,00)\end{array}$ & $\begin{array}{l}7,7550 \\
(0,00)\end{array}$ & $\begin{array}{c}26,2790 \\
(0,00)\end{array}$ & $\begin{array}{c}15,3010 \\
(0,00)\end{array}$ \\
\hline
\end{tabular}


a positive effect on financial performance indicators. When the fact that Intellectual capital can be considered as a financial performance indicator, making a comparison would not be an incorrect evaluation. However, unlike this study, Pae et al. (2005), Qiang (2007), and Sofian et al. (2011) determined a negative relationship between accounting conservatism and the ratio of the market value to the book value.

\section{RESULTS AND DISCUSSION}

The evaluations of the findings, the effect of accounting conservatism on intellectual capital and the level of accounting conservatism are given in Table 15 and 16.
- Accepted (for MVA dependent variable) - Sector $M$ in Basu Model

- Accepted (for MTB/ICP, VAIC and MVA dependent variables) - Sector F in Basu Model

- Accepted (for MVA dependent variable) - Sector $M$ in Beaver and Ryan Model

- Accepted (for MVA dependent variable) - Sector $F$ in Beaver and Ryan Model

- Accepted (for MTB/ICP and VAIC dependent variables) - Sector F in Ball and Shivakumar Model

- Accepted (for MTB/ICP and VAIC dependent variables) - Sector M in Givoly and Hayn Model

- Accepted (for VAIC and Approximately Tobin Q dependent variables) - Sector F in Givoly and Hayn Model

Table 15: The effect of Accounting Conservatism on Intellectual Capital

\begin{tabular}{|c|c|c|c|c|c|c|}
\hline & Sectors & $\begin{array}{c}\text { MTB or } \\
\text { ICP (The } \\
\text { common } \\
\text { model in } \\
\text { the } \\
\text { Literature) }\end{array}$ & $\begin{array}{c}\text { VAIC } \\
\text { (Public, } \\
\text { 1998) }\end{array}$ & $\begin{array}{c}\text { Approximately } \\
\text { Tobin Q } \\
\text { (Chung and } \\
\text { Pruitt, 1994) }\end{array}$ & $\begin{array}{c}\text { MVA } \\
\text { (Stern } \\
\text { Stewart } \\
\text { Counselling } \\
\text { Business }\end{array}$ & Hypothesis \\
\hline \multirow{2}{*}{ Basu (1998) } & $\mathrm{M}$ & $x$ & $x$ & $x$ & + & Accepted \\
\hline & $\mathrm{F}$ & + & - & $x$ & + & Accepted \\
\hline \multirow{2}{*}{$\begin{array}{l}\text { Beaver and } \\
\text { Ryan (2000) }\end{array}$} & $\mathrm{M}$ & $x$ & $x$ & $x$ & + & Accepted \\
\hline & $\mathrm{F}$ & $x$ & $x$ & $x$ & + & Accepted \\
\hline \multirow{2}{*}{$\begin{array}{l}\text { Ball and } \\
\text { Shivakumar } \\
(2005)\end{array}$} & $\mathrm{M}$ & $x$ & $x$ & $x$ & $x$ & Rejected \\
\hline & $\mathrm{F}$ & + & + & $x$ & $x$ & Accepted \\
\hline \multirow{2}{*}{$\begin{array}{l}\text { Givoly and } \\
\text { Hayn (2000) }\end{array}$} & $\mathrm{M}$ & + & + & $x$ & $x$ & Accepted \\
\hline & $\mathrm{F}$ & $x$ & + & + & $x$ & Accepted \\
\hline
\end{tabular}

Table 16: The Level of Accounting Conservatism

\begin{tabular}{|c|c|c|c|c|}
\hline & Sectors & Asymmetry & Coefficients & The Level of AC \\
\hline \multirow{2}{*}{ Basu (1998) } & $\mathrm{M}$ & No & 0,0395 & Low \\
\hline & $\mathrm{F}$ & No & $-0,3598$ & Low \\
\hline \multirow{2}{*}{$\begin{array}{l}\text { Beaver and Ryan } \\
(2000)\end{array}$} & M & $\begin{array}{c}\text { See the graphics } \\
\text { in appendix }\end{array}$ & $\begin{array}{l}\text { Bias component } \\
\text { is high when } \\
\text { MVA is selected. }\end{array}$ & High \\
\hline & $\mathrm{F}$ & $\begin{array}{c}\text { See the graphics } \\
\text { in appendix }\end{array}$ & $\begin{array}{l}\text { Bias component } \\
\text { is high when } \\
\text { MVA is selected. }\end{array}$ & High \\
\hline \multirow{2}{*}{$\begin{array}{l}\text { Ball and } \\
\text { Shivakumar (2005) }\end{array}$} & $\mathrm{M}$ & Yes & 1,7479 & High \\
\hline & $\mathrm{F}$ & Yes & $-0,4537$ & High \\
\hline \multirow{2}{*}{$\begin{array}{l}\text { Givoly and Hayn } \\
\text { (2000) }\end{array}$} & M & See the figure 1 & $\begin{array}{c}\text { The graph-line is } \\
\text { negative } \\
\text { directional. }\end{array}$ & High \\
\hline & $\mathrm{F}$ & See the figure 1 & $\begin{array}{c}\text { The graph-line is } \\
\text { negative } \\
\text { directional. }\end{array}$ & High \\
\hline
\end{tabular}


As given in Table 15 and 16 as a brief summary, it was determined as a result of the analyses that;

- Accounting conservatism has a positive effect on intellectual capital. This is more prominent on financial institutions,

- Accounting conservatism, which was measured only (for the VAIC dependent variable) according to Asymmetric Timing of Earnings (i.e. the Basu Model) has a negative effect on intellectual capital,

- All of the research hypotheses have been accepted (Except for H3: Accounting conservatism, which is measured according to the asymmetry of accruals and cash flows, has an effect on intellectual capital in manufacturing industry),

- The highest number of positive effects is seen on intellectual capital measured by MVA method, the least number of positive effects is seen on intellectual capital measured by approximately Tobin Q,

- The companies of manufacturing industry and financial institutions have high levels of conservatism (except for Basu Model),

\section{CONCLUSION}

Since accounting conservatism ensures that;

- the benefit of business stakeholders is increased,

- the business is protected against risky situations,

- the financial statements of the enterprises are adjusted to real values,

- the number of commercial cases involving the enterprise is reduced, and

- the audit costs are minimized,

it is cared about by relevant parties, and the opinions in favor of it become widespread in the literature (Watts, 2002; Ahmed and Duellman, 2007; Ettredge et al., 2016). However, there are also some counterarguments -although a few- claiming that accounting conservatism causes manipulation of financial information, and causes that misunderstandings appear about the assets, foreign sources and revenues and expenses of the enterprise (Xie, 2015; Feltham and Ohlson, 1995; Zhang, 2000).

The enterprise can convert its raw data into human capital and customer capital, and increase the market value of the enterprise by including the increase and management of the intellectual capital in this pro- cess, and by managing information. Although some authors in the literature (Brooking, 1997; Bontis, 1998) consider intellectual capital as an equivalent concept to the unearned increments concept in accounting at a descriptive level, the important elements host by intellectual capital (i.e. knowledge, education, technology, etc.), and the fact that it cannot be calculated as easily as unearned increments makes it quite different from unearned increments.

In this respect, it is noteworthy that several studies in the literature argue that conservative accounting applications suppress intellectual capital (Sofian et al., 2011), and although not directly related, emphasize the negative aspects of the relationship between accounting conservatism and intellectual capital (Amir and Lev, 1996; Brennan, 2001; Lev, 2001; Holland, 2003). However, the fact that the subjects with which accounting conservatism was investigated (corporate social responsibility, auditing and auditor quality, management of earnings, etc.) have common aspects with intellectual capital, accounting conservatism aims to protect the interests of the parties of the enterprise. Besides, intellectual capital is also a part of this aim for taking the business further may provide a more positive approach to the relationship between accounting conservatism and intellectual capital. In addition, it is also possible to argue that every enterprise maintaining its existence contributes to the accumulation of intellectual capital. In summary, it is possible to bring alternative and more positive viewpoints about the opinions that conservative reporting prevents intellectual capital from becoming prominent in the literature (Bellikli, 2019).

In the light of the theoretical explanations on accounting conservatism and intellectual capital given above, the relationship between accounting conservatism and intellectual capital was dealt with in this study. For the purpose of revealing this relationship, accounting conservatism and intellectual capital were measured separately by considering the measurement methods in the literature and on two different sectors, and the effect of accounting conservatism on intellectual capital was investigated with the help of panel data analysis.

When the findings that were obtained as a result of the analyses are evaluated briefly, the following conclusions may be made;

- The conservatism levels of the companies that were included in the analyses were low in one 
measurement method (Basu, 1997), which was determined collectively with a general coefficient, and were high in two measurement methods (Givoly and Hayn, 2000; Ball and Shivakumar, 2005);

- The companies that were included in the analyses have conservative accounting policies in the measurement method that was determined with separate coefficients (Beaver and Ryan, 2000),

- Three of the measurement methods have yielded consistent results in terms of levels of conservatism,

- Considering that the intellectual capitals of the companies that were included in the analysis had positive values in average according to the measurement methods, intellectual capital is cared by the companies,

- Accounting conservatism has a positive effect on intellectual capital. This is more prominent on financial institutions, accounting conservatism, which was measured only (for the VAIC dependent variable) according to Asymmetric Timing of Earnings (i.e. the Basu Model) has a negative effect on intellectual capital.

- It may be concluded and hypothesized that only one of the accounting conservatism measurement methods (Ball and Shivakumar, 2005) that was applied in the study had no effects on intellectual capital in manufacturing industry.
On the other hand, three of the measurement methods have yielded consistent results in terms of levels of conservatism in this study. Measurement methods based on the same principles (Basu-Ball and Shivakumar) have yielded consistent results for both sectors. But its have yielded different results for levels of conservatism. It may be recommended for future studies that authors can use measurement methods that give consistent results or measurement methods based on the same principles (Basu-Ball and Shivakumar) in this study. However, the effect of accounting conservatism on intellectual capital is re-examined with different business data, and studies are conducted with the companies that are not listed in the Stock Exchange and/or with comparative country examples.

\section{Acknowledgements}

This study was derived from the doctoral dissertation with the title "The Effect of Accounting Conservatism on Intellectual Capital: A Survey on Listed Borsa Istanbul (BIST) 100 Index", written by Ugur BELLIKLI under the supervision of Prof. Dr. Abdulkerim DAŞTAN in Karadeniz Technical University, Social Sciences Institute, Business Administration Department. We would like to thank Assoc. Prof. Dr. Zehra ABDIOĞLU, Prof. Dr. Yusuf SÜRMEN, Prof. Dr. Ahmet Hayri DURMUS and Prof. Dr. Dursun ARIKBOGA for their precious contributions to enable the completion of the present study. 


\section{REFERENCES}

Ahmed, A. S. \& Duellman, S. (2007). Accounting conservatism and board of director characteristics: An empirical analysis, Journal of Accounting and Economics, 43(2-3), 411-437.

Akmeşe, H. (2006). Entellektüel sermayenin firma piyasa değeri üzerine etkisi ve IMKB'de işlem gören şirketler üzerinde bir araştırma, Master Thesis, Selçuk University-Institute of Social Sciences.

Amir, E. \& Lev, B. (1996). Value-relevance of nonfinancial information: The wireless communications industry, Journal of Accounting and Economics, 22(1-3), 3-30.

Ball, R. \& Shivakumar, L. (2006). The role of accruals in asymmetrically timely gain and loss recognition, Journal of Accounting Research, 44, 207-242.

Basu, S. (1997). The conservatism principle and the asymmetric timeliness of earnings. Journal of Accounting and Economics, 24(1), 3-37.

Bayraktaroglu, A. E., Calisir, F., Baskak, M. (2014). Kimya, petrol, plastik sektöründeki firmalarda 1. ve 2. ulusal pazar açısından entelektüel sermaye kullanım etkinliği ve pazar performansı ilişkisi, Eskişehir Osmangazi University, Journal of Economics and Administrative Sciences, 9(3), 25-47.

Bayraktaroglu, A. E., Calisir, F., Baskak, M. (2019). Intellectual capital and firm performance: an extended VAIC model, Journal of Intellectual Capital, 20 (3), 406-425.

Beaver, W. H. \& Ryan, S. G. (2000). Biases and lags in book value and their effects on the ability of the book-to-market ratio to predict book return on equity, Journal of Accounting Research, 38(1), 127-148.

Bellikli, U. (2019). Muhasebe muhafazakarlığının entelektüel sermaye üzerindeki etkisi: Borsa Istanbul (BIST) 100 Endeksi'ndeki işletmelerde bir araştırma, Doctoral Dissertation, Karadeniz Technical University-Institute of Social Sciences.

Bontis, N. (1998). Intellectual capital: An exploratory study that develops measures and models, Management Decision, 36(2), 63-76.

Bontis, N. (2001). Assessing knowledge assets: A review of the models used to measure intellectual capital, Journal of Management Reviews, 3(1), 41-60.

Brennan, N. (2001). Reporting intellectual capital in annual reports: Evidence from Ireland, Accounting, Auditing \& Accountability Journal, 14(4), 423-436.

Brooking, A. (1997). The management of intellectual capital, Long Range Planning, 30(3), 364-365.

Carroll, R. F. \& Tansey, R. R. (2000). Intellectual capital in the new internet economy - Its meaning, measurement, and management for enhancing quality, Journal of Intellectual Capital, 1(4), 296-312.

Celik, A. E. \& Percin, S. (2000). Entelektüel sermayenin işletme bazında ölçülmesi ve değerlendirilmesi, Accounting and Auditing Review, 2, 111-118.
Cenciarelli, V. G., Greco, G., Allegrini, M. (2018). Does intellectual capital help predict bankruptcy? Journal of Intellectual Capital, 19(2), 321-337.

Chandra, U., Wasley, C. E., Waymire, G. B. (2004). Income conservatism in the U.S. technology sector, Simon School Working Paper, No. FR 04-01, 2-61.

Chen, M. C., Cheng, S. J., Hwang, Y. (2005). An empirical investigation of the relationship between intellectual capital and firms' market value and financial performance, Journal of Intellectual Capital, 6(2), 159-176.

Chen, Y. (2019). Succession of family firms and accounting conservatism, Modern Economy, 10, 298-310.

Cheng, Q. (2005). What determines residual income?, The Accounting Review, 80(1), 85-112.

Chung, K. H. \& Pruitt, S. W. (1994). A simple approximation of Tobin's q, Financial Management, 23(3), 70-74.

Cıkrıkcı, M. \& Dastan, A. (2002). Entelektüel sermayenin temel finansal tablolar aracılığı ile sunulması, Bankacılar, 43, 18-32.

Crawley, M. J. (2015), Macroeconomic consequences of accounting: The effect of accounting conservatism on macroeconomic indicators and the money supply, The Accounting Review, 90(3), 987-1011.

Edvinsson, L. \& Malone, M. (1997) Intellectual capital. Harper Business, New York.

Edvinsson, L. (1997). Developing intellectual capital at skandia, Long Range Planning, 30(3), 366-373.

Ercan, M. K., Öztürk, M. B., Demirgüneş, K. (2003). Değere dayalı yönetim ve entelektüel sermaye, Gazi Kitabevi, Ankara.

Erkus, H. (2004). Geleneksel raporlama yöntemlerinin yeni ekonomi karşısındaki durumunun irdelenmesi ve entelektüel sermayenin raporlanması, Süleyman Demirel University Journal of Economics and Administrative Sciences, 9(2), 303-324.

Ettredge, M. L., Huang, Y., Weining, Z. (2016). Conservative reporting and securities class action lawsuits, Accounting Horizons, 30(1), 93-118.

Feltham, G. A. \& Ohlson, J. A. (1995). Valuation and clean surplus accounting for operating and financial activities, Contemporary Accounting Research, 11(2), 689-731.

Francis, B., Hasan, I., Wu, Q. (2013). The benefits of conservative accounting to shareholders: Evidence from the financial crisis, Accounting Horizons, 27(2), 319-346.

Ge, R., Seybert N., Zhang, F. F. (2018). Investor sentiment and accounting conservatism, Accounting Horizons, 33(1), 83-102.

Givoly, D. \& Hayn, C. (2000). The changing time-series properties of earnings, cash flows and accruals: Has financial reporting become more conservative?, Journal of Accounting and Economics, 29(3), 287-320.

Gokmen, M. K. (2012). Koşula bağlı ihtiyatlııı ve karın getiriye yansıması üzerine ampirik bir araştırma, 19 Mayıs University Journal of Economics and Administrative Sciences, 6, 1667 1720. 
Hand, J. \& Lev, B. (2003). Intangible assets, values, measures and risk, Oxford University Press, New York Inc.

Holland, J. (2003). Intellectual capital and the capital market-organisation and competence, Accounting, Auditing \& Accountability Journal, 16(1), 39-48.

Kamath, G. B. (2008). Intellectual capital and corporate performance in Indian pharmaceutical Industry, Journal of Intellectual Capital, 9(4), 684-704.

Kaplan, R. S. \& Norton, D. P. (1999). Balanced scorecard: Şirket stratejisini eyleme dönüştürmek, (Transl. Serra Egeli), Sistem Yayıncılık, İstanbul.

Kendirli, S. \& Diker, F. (2016). Kâgıt ve ambalaj sanayi işletmelerinde entelektüel sermayenin finansal performansa etkisi, Journal of Accounting and Tax Practices, 9(1), 45-58.

Kim, K. S. (2004). Strategic planning for value-based management, Management Decision, 42(8), 938-948.

Krishnan, G. V. (2007). Did earnings conservatism Increase for former andersen clients?, Journal of Accounting, Auditing \& Finance, 22(2), 141-163.

LaFond, R. \& Watts, R. L. (2008). The information role of conservatism, The Accounting Review, 82(2), 447-478.

Lara, J. M. G., Osma, B. G., Penalva, F. (2009). Accounting conservatism and corporate governance, Review of Accounting Studies, 14(1), 161-201.

Leone, A. J., Wu, J. S., Zimmerman, J. L. (2006). Asymmetric sensitivity of ceo cash compensation to stock returns, Journal of Accounting and Economics, 42(1-2), 167-192.

Lev, B. (2001). Intangibles: management, measurement, and reporting, Washington, DC:The Brooking Institution.

Li, Q. \& Xu, L. (2018). Asset specificity and conditional accounting conservatism, Journal of Business Financial Accounting, 45, 839-870.

Martensson, M. (2000). A critical review of knowledge management as a management tool, Journal of Knowledge Management, 4(3), 204-216.

Mashayekhi, B., Abadi, M. M., Hesarzadeh, R. (2009). Accounting conservatism, earnings persistance and earnings distribution, Journal of the Accounting and Auditing Review, 56, 107-214.

McElroy, M. W. (2002). Social innovation capital, Journal of Intellectual Capital, 3(1), 30-39.

Ozkan, N., Cakan, S., Kayacan, M. (2017). Intellectual capital and financial performance: A study of the Turkish banking sector, Borsa Istanbul Review, 17(3), 190-198.

Pae, J., Thornton, D. B., Welker, M. (2005). The link between earnings conservatism and balance sheet conservatism, Queen's Univesity Working Paper.

Penman, S. H. \& Zhang, X. (2002). Accounting conservatism the quality of earnings, and stock returns, The Accounting Review, 77(2), 237-264.

Polat, Z. G. (2016). Muhasebede ihtiyatlılık ve kurumsal yönetim: Borsa Istanbul üzerine ampirik bir uygulama, Master Thesis, Dumlupınar University-Institute of Social Sciences.
Pulic, A. (1998). MVA and VAIC analysis of randomly selected companies from FTSE 250, Austrian Intellectual Capital Research Center, Graz-London, 1-41.

Pulic, A. (2004). Intellectual capital - Does it create or destroy value?, Measuring Business Excellence, 8(1), 62-68.

Qiang, X. (2007). The effects of contracting, litigation, regulation, and tax costs on conditional and unconditional conservatism: Cross-sectional evidence at the firm level, The Accounting Review, 82(3), 325-370.

Rodov, I. \& Leliaert, P. (2002). FIMIAM: Financial method of Intangible assets measurement, Journal of Intellectual Capital, 3(3), 323-336.

Samiloglu, Famil (2002). Entelektüel sermaye, Gazi Kitabevi, Ankara.

Sofian, S., Rasid, S. Z. A., Mehri, M. (2011). Conservatism of intellectual capital and relevance of earnings, International Journal of Business and Social Science, 2(10), 26-30.

Stewart, T. A. (1997). Entelektüel sermaye kuruluşların yeni zenginliği, (Transl. Nurettin Elhüseyni), Kontent Kitap, BZD Yayıncılık.

Unal, O. (2010). Entelektüel sermayenin raporlanması ve UMS 38 maddi olmayan duran varlıklar standardı kapsamında değerlendirilmesi, Journal of Trade and Tourism Education Faculty, 2, 20-39.

Van den Berg, H. A. (2002). Models of intellectual capital valuation: A comparative evaluation, Knowledge Summit Doctoral Consortium, 1-33.

Wang, R. Z. (2009). Accounting conservatism, Doctoral Dissertation, Victoria University, Wellington.

Wang, R. Z., Hogartaigh, C. O., Zijl, T. V. (2008). Measures of accounting conservatism: A construct validity perspective, Journal of Accounting Literature, 28, 1-60.

Watts, R. L. \& Zimmerman, J. L. (2003). Conservatism in accounting, Accounting Horizons, 17(4) 287-301.

Watts, R. L. (2002). Conservatism in accounting, Simon School of Business Working Paper, Working Paper Nr.: FR 02-21, The Bradley Policy Research Center.

Xie, Y.(2015). Confusion over accounting conservatism: A critical review, Australian Accounting Review Nr. 73, 25(2), 204-216.

Yalama, A. (2005). Entelektüel sermayenin entelektüel katma değer katsayısı (VAIC) ile ölçülmesi ve veri zarflama analizi (DEA) yöntemi kullanılarak karlılığa etkisinin sınanması: iMKB'ye kote bankalarda uygulaması, Master Thesis, Anadolu University-Institute of Social Sciences.

Zhang, X. J. (2000). Conservative accounting and equity valuation, Journal of Accounting and Economics, 29(1), 125-149.

Zor, I. \& Cengiz, S. (2013). Entelektüel sermaye ile firma değeri arasındaki ilişki: Borsa İstanbul'da bir araştırma, Çankırı Karatekin University Journal of Economics and Administrative Sciences, 3(1), 37-56. 


\section{Appendix - The Graphics of Inclination Component (Bias)}

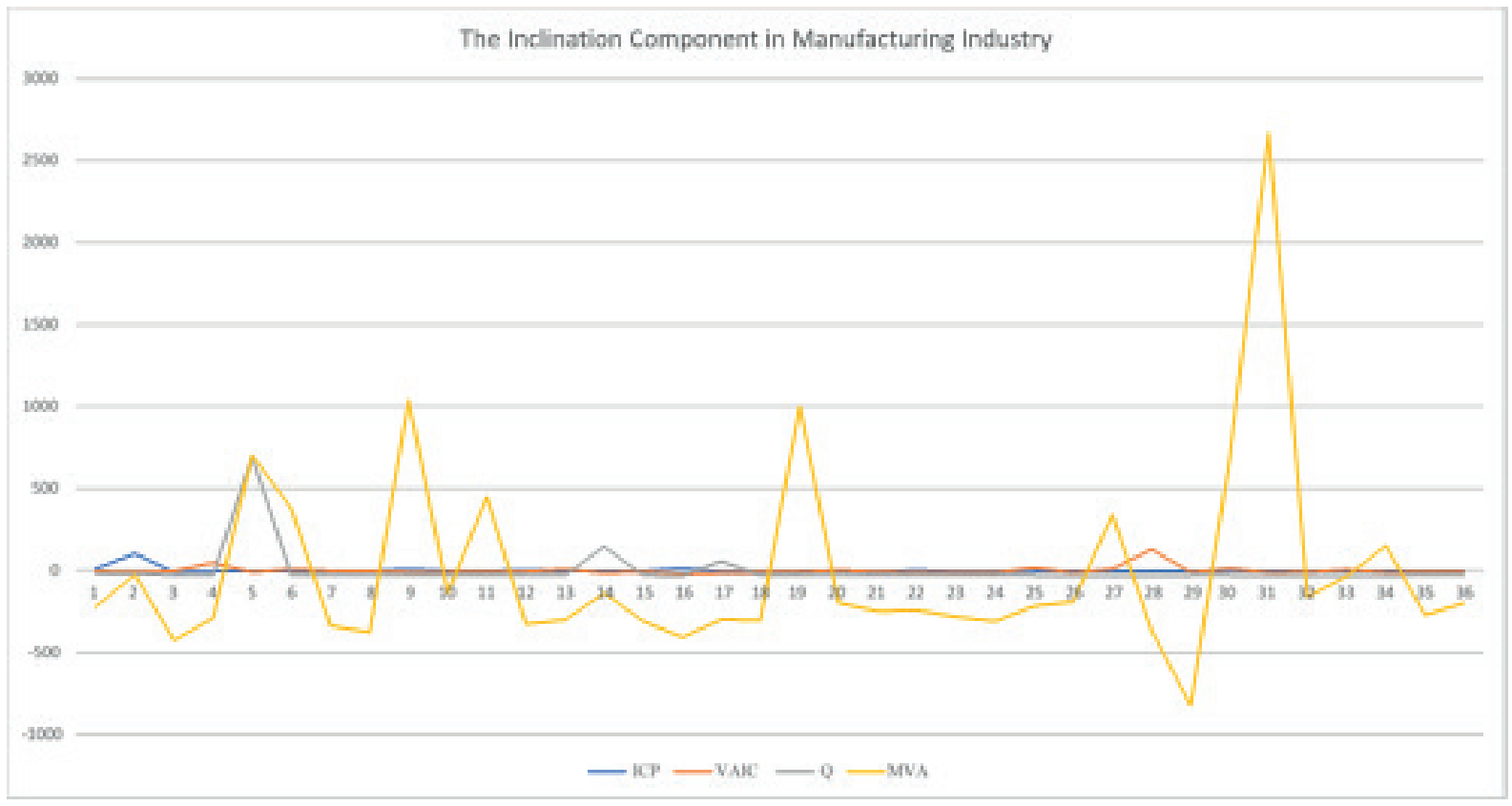

The Inclination Component in Financial Institutions

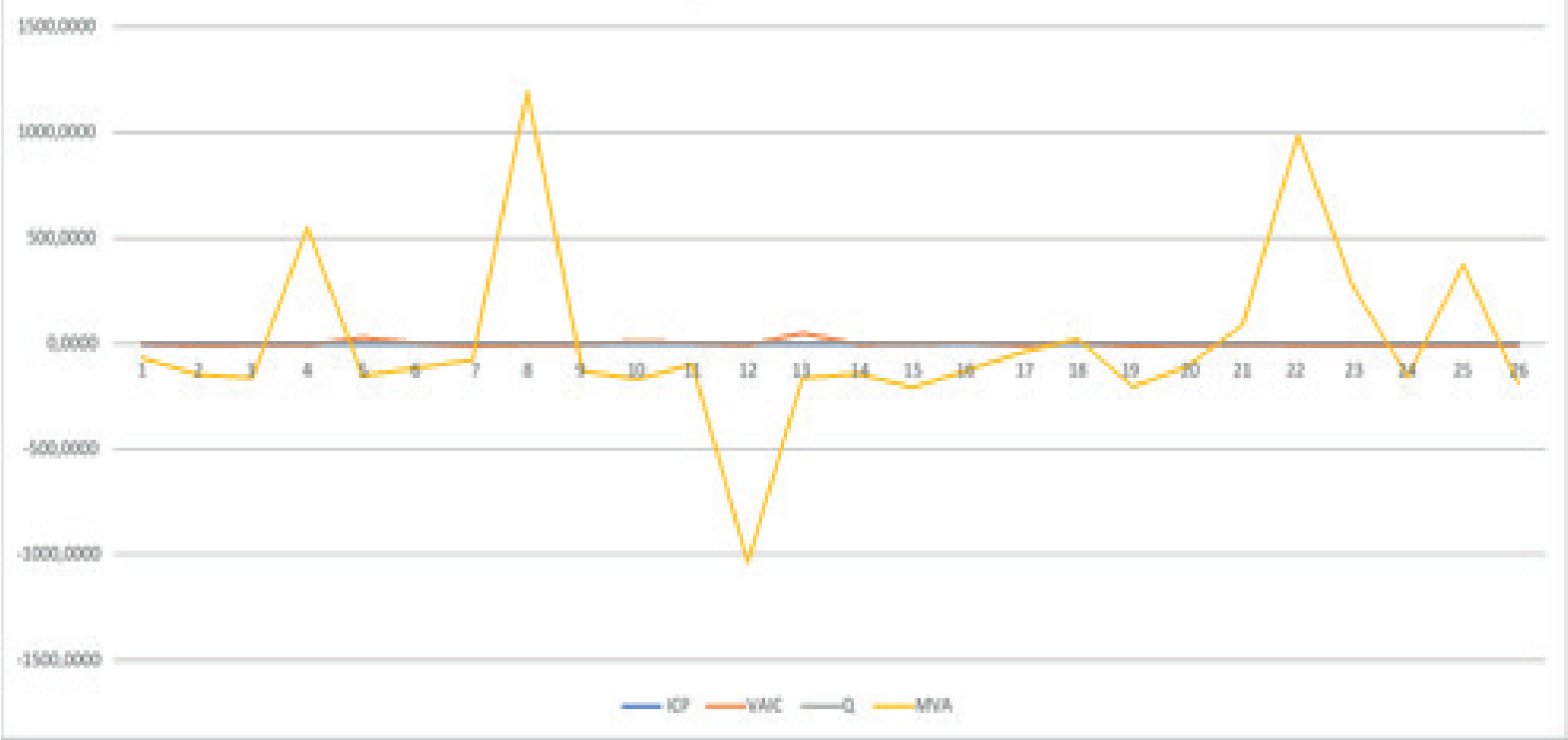

